\title{
Rule of Law and United Nations Interoperability
}

\begin{abstract}
Geoff Gilbert and Anna Magdalena Rüsch*

This article considers how a rule of law approach, central to the UN's activities since 2004, could facilitate the operationalization of interoperability across its agencies. But what is rule of law: the Anglo-American judicalized understanding or the civil law model, l'Etat de droit or Rechtsstaat, that is more rooted in the governance of the State? And while a State that increasingly adopts a rule of law stance will, with the support of the UN, better protect and empower all persons on its territory, the UN itself must also uphold the rule of law. The crucible of displacement is used to put these arguments to the test, since this highlights the essentially Westphalian framework of international law and practice, as it involves more than one State and more than one UN operation.
\end{abstract}

\section{INTRODUCTION}

\footnotetext{
* Geoff Gilbert, Professor of International Human Rights \& Humanitarian Law, University of Essex, geoff@essex.ac.uk; Anna Magdalena Rüsch, Associate RSD Officer, UNHCR, amruesch@yahoo.de.
}

Acknowledgements: The authors are extremely grateful to UNHCR, Division of International Protection, for the opportunity to undertake a consultancy on rule of law and its relevance to solutions from August 2014 to January 2015, which included field visits to Niger and Colombia. They are also indebted to the various academics at Essex and at various conferences for their input on earlier drafts and presentations, especially Sabine Michalowski, Clara Sandoval, Lorna McGregor, Paul Hunt, Ahmed Shaheed, Noam Lubell, Daragh Murray, Sheldon Leader, Tom Cornford, Clotilde Pégorier, Laure Sauve and Julien Sterck. Needless to add, the views expressed and any errors are the authors' own and do not reflect those of any organization with which they might be associated. 
The Secretary-General's 2004 Report on the rule of law and transitional justice in conflict and post-conflict societies endorsed the centrality of rule of law to the UN. ${ }^{1}$ This was affirmed by the High Level Meeting of the General Assembly of 2012. ${ }^{2}$ This article addresses the application of the rule of law to United Nations (UN) operations, sometimes across borders, as well as to the UN itself, as an international organization seeking to provide a co-ordinated response to global crises or, in the UN's words, 'Delivering as One'.

The phrase 'rule of law' is sometimes used by lawyers and non-lawyers without the degree of precision that would make it a useful measure of progress and achievement. Indeed, as that criticism indicates, in this article the principle should be understood as both a process and an end goal. ${ }^{3}$ Before one can explore its application, however, it is essential to

${ }^{1}$ Report of the Secretary-General, S/2004/616 (23 August 2004) para 6: "The "rule of law" is a concept at the very heart of the Organization's mission. It refers to a principle of governance in which all persons, institutions and entities, public and private, including the State itself, are accountable to laws that are publicly promulgated, equally enforced and independently adjudicated, and which are consistent with international human rights norms and standards. It requires, as well, measures to ensure adherence to the principles of supremacy of law, equality before the law, accountability to the law, fairness in the application of the law, separation of powers, participation in decision-making, legal certainty, avoidance of arbitrariness and procedural and legal transparency'. Neither the General Assembly nor the Security Council has ever adopted this definition, although GA res 60/1 (24 October 2005) adopts some of the same ideas. The UN approach to rule of law is discussed at length below. See Robert McCorquodale, 'Defining the International Rule of Law: Defying Gravity?’ (2016) 65 International \& Comparative Law Quarterly 277.

${ }^{2}$ UNGA res 67/1 (24 September 2012) para 2. There have been a series of GA Resolutions since 2005 - the latest can be found at UNGA res 71/148 (13 December 2016), which calls for: ' 20 .... strengthening [of] the rule of law through access to justice, including with regard to the provision of birth registration for all, appropriate registration and documentation of refugees, migrants, asylum seekers and stateless persons'. See Key Documents at $<$ www.un.org/ruleoflaw/keydocuments $>$.

${ }^{3}$ Compare McCorquodale (n 1) 290-91, he talks of degrees of rule of law compliance, which fails to recognise that rule of law is a process, especially given that no State could ever fully attain the rule of law. See Martin Krygier on the teleological account of the rule of law: 'Rule of Law (and Rechtsstaat)' in James D Wright (ed), International Encyclopaedia 
consider the different levels at which rule of law operates; the different understandings of rule of law, something that is rarely addressed; and the overlap with similar concepts, which can help to explain, and yet risk confusing, both its reach and its potential impact. The article looks, first, at conceptions of the rule of law in different legal systems and then at how it might be applied vis à vis international organizations, particularly the UN. The article examines how the rule of law might facilitate UN interoperability, that is, how the UN's various agencies can utilize the principle, as it is understood within the organization, so as to promote an integrated response. To highlight the value of rule of law to international organizations operating across borders, the article uses examples drawn from the context of protracted displacement, involving, as it does, more than one State, more than one UN operation. Studies of rule of law in the UN have usually focused on how well or poorly it has worked in particular instances. ${ }^{4}$ This article, on the other hand, looks at its potential to promote durable solutions through interoperability within the UN, enhancing State capacity and promoting the international protection of individuals. Since, however, the principle also requires the UN itself to uphold the rule of law, the final section of the article looks at how this might be put into practice so that, where possible, this might also enhance interoperability.

\subsection{Why displacement?}

Mass displacement of individuals, as well as being highly pertinent and topical, ${ }^{5}$ provides a challenging framework for considering rule of law in the UN. As indicated, it will usually

of the Social and Behavioural Sciences (2nd edn, vol 20, 2015) 780, 785; and Martin Loughlin, Foundations of Public Law (2010) ch 11: 'Rechtsstaat, Rule of Law, l'Etat de droit' $312-41$.

${ }^{4}$ For an interesting critique of the UN's approach to rule of law, see David Marshall (ed), The International Rule of Law Movement: A Crisis of Legitimacy and the Way Forward (2014).

${ }^{5}$ UNHCR, 'Global Trends: Forced Displacement in 2016'

$<\mathrm{http}: / /$ www.unhcr.org/5943e8a34>, indicates that there were 65.6 million individuals of concern to UNHCR in 2016. See Secretary-General's Report, 'In Safety and Dignity: Addressing Large Movements of Refugees and Migrants' UN doc A/70/59 (21 April 2016) $<$ http://www.un.org/en/ga/search/view_doc.asp?symbol=A/70/59\&=E\%20>, the outcome document for the high-level plenary meeting of the General Assembly held on 19 September 2016; and GA res 71/1 (19 September 2016) (New York Declaration), Annex I 
affect more than one sovereign State, probably more than one UN operation, and several different UN actors. A lack of the rule of law will be part of the cause of individuals fleeing and its restoration will be needed to promote return. However, those displaced will impact on rule of law in the host State. As no one UN agency can facilitate rule of law on its own, it requires interoperability. Finally, since those displaced often rely on the UN to provide protection, the UN's own rule of law responsibilities will be engaged. Thus, displacement brings into sharp relief a range of issues regarding rule of law and the UN.

The UN agency with primary responsibility for displaced persons is the UN High Commissioner for Refugees (UNHCR); it provides international protection to refugees and seeks permanent solutions by assisting governments. ${ }^{6}$ UNHCR has an extended mandate to protect refugees, returnees, and asylum seekers; to take the lead on the protection of conflict IDPs; and to co-lead on shelter, camp co-ordination, and camp management. According to Türk and Eyster, 'UNHCR is primarily mandated to provide international protection and humanitarian assistance and to seek permanent solutions for persons within its competence',

(Comprehensive Refugee Response Framework) and Annex II (Towards a Global Compact for Safe, Orderly and Regular Migration). The dearth of references to IDPs is a cause of concern - see UNHCR, Conclusion of the Executive Committee on international cooperation from a protection and solutions perspective No 112 (LXVII) (6 October 2016) Preamble $<$ http://www.refworld.org/docid/57f7b5f74.html>. See also Elizabeth Ferris, 'In Search of Commitments: The 2016 Refugee Summits'; Volker Türk, 'The New York Declaration: Once in a Lifetime Opportunity to Enhance Refugee Protection'; and Geoff Gilbert, 'Glimmers of Hope' - all Kaldor publications available at $<$ http://www.kaldorcentre.unsw.edu.au/september-summits-refugees-backgroundcommentary-and-resources>; and, Volker Türk and Madeline Garlick, 'From Burdens and Responsibilities to Opportunities: the Comprehensive Refugee Response Framework and a Global Compact on Refugees' (2016) 28 International Journal of Refugee Law 656.

${ }^{6}$ Statute of the Office of UNHCR, UNGA res 428 (V) (14 December 1950) paras 1 and 8a; Convention relating to the Status of Refugees, 1951, 189 UNTS 137 (28 July 1951), arts 35 and 36; and 1967 Protocol, 606 UNTS 267 (16 December 1966), art II; and $<$ http://www.refworld.org/idps.html $>$. Although many of the problems displaced and stateless persons face are so similar in practice, this article is focused on refugees, asylum seekers, returnees, and internally displaced persons.

${ }^{7}$ Volker Türk and Elizabeth Eyster, 'Strengthening Accountability in UNHCR' (2010) 22 International Journal of Refugee Law 159, 162 and 163 (footnotes omitted). 
that is, not just refugees and stateless persons but, in certain circumstances, IDPs too. The functions of UNHCR have expanded considerably over time. As Türk and Eyster go on to point out:

Mandated activities include preventive action and participation "at the invitation of the Secretary-General, in those humanitarian endeavours of the United Nations for which his Office has particular expertise and experience". In addition, the institution of 'good offices' and the right to humanitarian initiative have been useful tools for situations outside mandated activities, while other functions include relief distribution, emergency preparedness, special humanitarian activities, broader development work, and issuance of documentation for persons falling under the mandate.

Therefore, this broadened mandate of protection and humanitarian assistance, underpinned by international human rights law, establishes a series of obligations owed to displaced persons where rule of law principles could provide the framework for application. Further, given the average length of displacement situations tends towards 20 years, UNHCR's protection mandate has to be seen as parallel to the development frameworks promoted by UNDP and other UN actors with the State for all those on the State's territory UNHCR protection does not mean displaced individuals are in some parallel State. A proper implementation of a rule of law approach demands, at State level and within the organization, UN interoperability. Durable and sustainable solutions for displaced persons depend on the realization of several rights during protracted displacements, such as the right to education, to property, or to the provision of documents. While such rights could be accorded to refugees and asylum seekers within the framework of the 1951 Convention, they could also be seen as a society upholding a substantive/thick rule of law, the sort promoted, as will be discussed, by the UN: thus, the reach of the rights would be broader as would the range of intended beneficiaries. ${ }^{8}$ Moreover, other UN actors that utilize a rule of law approach, especially those whose primary focus is development, would assist in ensuring that on-going solutions whilst displaced are part of a wider national plan that would aim to benefit both the displaced population and the host population to the same degree: the aim being that displaced persons would move towards achieving durable and sustainable

${ }^{8}$ See eg the right to education, art 22, 1951 Convention (n 6), compared to arts 28, 29 and 32 of the Convention on the Rights of the Child, UNGA res 44/25 (20 November 1989); or art 13, International Covenant on Economic, Social and Cultural Rights (16 December 1966) 993 UNTS 3. 
solutions. For example, in Colombia, the government, UNDP, and UNHCR formulated the Transitional Solutions Initiative (TSI) $;{ }^{9}$ with $6,000,000$ internally displaced persons (IDPs) as a result of the 50 year conflict, the TSI sought to facilitate resolution of the displacement of 17 communities through return, relocation, or local integration. ${ }^{10}$ What made the TSI special was that it aimed to understand the problems of internal displacement in substantive/thick rule of law terms so as to identify and engage with possible partners, such as other UN actors, the government, as well as NGOs, in order to facilitate and channel the work that was already being carried out. In the five initial TSI locations across the country, one of the first activities undertaken was the provision of legal advice on land ownership rights, a quintessential rule of law response to displacement. In Niger, as another example, the government and UNHCR established zones d'accueil des réfugiés for nomadic herders from Mali: after registering as refugees/asylum seekers with the Commission Nationale d'Eligibilité au Statut du Réfugié, the Malians were given grazing rights for their animals across a swathe of Nigerien territory in order to preserve their way of life and to uphold their right to work, obligations of States parties to the 1951 Convention relating to the Status of Refugees. $^{11}$

These two examples indicate the way rule of law can provide frameworks for operationalizing a solutions-oriented approach within the UN. States upholding the rule of law will, with the assistance of the UN, enable access to rights for all those within their territory and jurisdiction. As a result, forcibly displaced persons, possibly the most vulnerable group in international law, lacking a State to protect them, can move towards achieving durable and sustainable solutions.

\section{WHAT THE RULE OF LAW IS AND IS NOT ... AND WHAT IT REALLY IS IN THIS CONTEXT}

\footnotetext{
${ }^{9}$ On TSIs generally, see UNHCR, 'Concept Note: Transitional Solutions Initiative - UNDP and UNHCR in collaboration with the World Bank' (2010)

$<$ http://www.refworld.org/docid/517511934.html>.

${ }^{10}$ See UNHCR's information page on Colombia for $2016<\mathrm{http}$ ://www.unhcr.org $>$ and the 2016 Plan $<$ http://reporting.unhcr.org/node/2542?y=2016\#year $>$.

${ }^{11}$ See, Intikane Refugee Hosting Area $<$ https://data2.unhcr.org/en/country/ner $>$ and associated documents. On the right to work as a self-employed person, see 1951 Convention (n 6) art 18.
} 
While rule of law at the domestic and international levels has been investigated in depth by legal theorists and constitutional specialists, with respect to international organizations, especially the UN, there is still no single, accepted understanding of its application and implementation. ${ }^{12}$ It is fair to say that rule of law is a concept with many meanings, possibly too many, ${ }^{13}$ and there is, in addition, overlap with related concepts, such as good governance, due process, and global administrative law. ${ }^{14}$ How does one bring all this together to give some clarity and focus to rule of law for the UN in the context of displacement so that it can be a useful measure of progress and achievement?

Rule of law is spoken about in relation to domestic legal systems and international law with a degree of osmotic fluidity, with only rare acknowledgement that ideas may not be transferable and transposable between these different regimes. Rule of law is always a product of the legal culture and community in which it is developed. ${ }^{15}$ Within a State, the rule of law, to the extent it applies at all, is established by the community and applied to the structures of centralized government in line with the community's values and interests and through whatever constitutional documents that are adopted. States choose their own constitutional norms and the nature of political participation is self-determined. Moreover, each State, no matter how riven internally, is always more cohesive than the 'international community'. The looser configuration of international society, which lacks any central government, makes it significantly less structured but, even here, the rule of law is a set of

${ }^{12}$ See José E Alvarez, 'International Organizations and the Rule of Law' (2016) 14 New Zealand Journal of Public and International Law 3. See also European Commission for Democracy through Law (Venice Commission), 'Report on the Rule of Law', adopted by the Venice Commission at its 86th plenary session (Venice, 25-26 March 2011) $<$ http://www.venice.coe.int/webforms/documents/?pdf=CDL-AD(2011)003rev-e>; and McCorquodale (n 1) 278.

${ }^{13}$ See Loughlin (n 3) 312; Krygier (n 3) 780; Duncan Fairgrieve, 'Etat de Droit and Rule of Law: Comparing Concepts - A Tribute to Roger Errera' [2015] Public Law 40.

${ }^{14}$ See Carol Harlow, 'Global Administrative Law: The Quest for Principles and Values' (2006) 17 European Journal of International Law 187. See also, Gianluigi Palombella, 'The Rule of Law as an Institutional Ideal' in Leonardo Morlino and Gianluigi Palombella (eds), Rule of Law and Democracy (2010) 3.

${ }^{15}$ Sir Arthur Watts, 'The International Rule of Law' (1993) 36 German Yearbook of International Law 15; Krygier (n 3) 784; Palombella (n 14) 33-34. 
rules for a community of States created by those States, who are the primary actors in this case. ${ }^{16}$ In line with international law generally, international rule of law has to be consensual, it reflects what States have voluntarily adopted. ${ }^{17}$ Rule of law on the international plane as it applies to States and to international organizations, therefore, must require even more nuanced distinctions. ${ }^{18}$ With respect to international organizations, rule of law has to be 'soft' in one sense, because their mandates, laid down in their founding instruments, constrain what they can and cannot do, and those are set out not by the international organization itself, but by the 'parent' States. ${ }^{19}$ Thus, rule of law for international organizations is not solely self-determined and could be described as 'soft' (in the same way that soft law still looks like law) because it lacks certain intrinsic attributes of domestic and even international rule of law. ${ }^{20}$

2.1 Whose rule of law?

\footnotetext{
${ }^{16}$ See Michael Zürn, André Nollkaemper and Randall Peerenboom (eds), Rule of Law Dynamics: In an Era of International and Transnational Governance (Cambridge University Press 2012).

${ }^{17}$ Watts (n 15). Compare Benedict Kingsbury, Nico Krisch, and Richard B Stewart, 'The Emergence of Global Administrative Law' (2005) 68 Law and Contemporary Problems 15. See also both Machiko Kanetake and André Nollkaemper (eds), The Rule of Law at the National and International Levels: Contestation and Deference (2016); and Devika Hovell, 'Due Process in the United Nations' (2016) 110 American Journal of International Law 1, who place undue emphasis on what happens in courts and tribunals in discerning rule of law and due process at the international level; given Hovell's focus on due process, that is more understandable, but she is claiming to apply due process to the $\mathrm{UN}$ as an organization.

${ }^{18}$ See also Simon Chesterman, 'An International Rule of Law' (2008) 56 American Journal of Comparative Law 331; and Thomas Bingham, The Rule of Law (2010).

${ }^{19}$ Thus, the international organization is a secondary actor for this purpose.

${ }^{20}$ See Ekaterina Y Krivenko, 'Revisiting the Reservations Dialogue: Negotiating Diversity while Preserving Universality through Human Rights Law' in Kanetake and Nolkaemper (eds) (n 17) 289, 296.
} 
Starting with the domestic level, it is not enough to simply try to distinguish between procedural and substantive understandings or the 'thin-thick' debate. ${ }^{21}$ Before that discussion, the rule of law in the Anglo-American tradition has to be compared with that in the civil law, Rechtsstaat and l'Etat de droit: ${ }^{22}$ both conceptions, taken together, may better underpin implementation in the context of an international organization, particularly the UN. As Loughlin makes clear, ${ }^{23}$ the Anglo-American approach has been refined through the courts and, in many ways, it is about judicial control of the other branches of government so that the law governs all actors within the State. ${ }^{24}$ As Krygier points out, ${ }^{25}$ the common law approach sees rule of law as separate from and as a 'restraint on the state' and as granting liberty by constraining the sovereign. The danger is that it leads to a very judicialized understanding, one that is slightly at odds with the UN's framework, where courts are generally less in evidence at the international level, and even more so in regard to international organizations; the International Court of Justice lacks general compulsory jurisdiction and international organizations can only seek Advisory Opinions. ${ }^{26}$ Leading common law theorists on the jurisprudence of rule of law, Raz, ${ }^{27}$ Fuller $^{28}$ and Dworkin, ${ }^{29}$ in

${ }^{21}$ See Krygier (n 3 ) 783-84. The debate was developed further by Paul P Craig, 'Formal and Substantive Conceptions of the Rule of Law: An Analytical Framework' [1997] Public Law 466.

${ }^{22}$ Although there are differences, l'Etat de droit draws heavily on the German understanding developed in the late 19th century - see Raymond Carré de Malberg, Contribution à la Théorie générale de l'Etat (Sirey 1920, reprinted Dalloz 2004) vol 1, s 164, esp 488 fn 5, and 492-93; see also Francis Hamon and Michel Troper, Droit Constitutionnel 2016-17 (37th edn, LGDJ) ss 34 and 68.

${ }^{23}$ See Loughlin (n 3 ) 315-17.

${ }^{24}$ See Albert V Dicey and Emlyn CS Wade, Introduction to the Study of the Law of the Constitution (10th edn, 1959).

${ }^{25}$ See Krygier (n 3) 781-83.

${ }^{26}$ UN Charter, ch XIV, esp art 96.

${ }^{27}$ Joseph Raz, The Rule of Law and its Virtue in Joseph Raz (ed), The Authority of Law: Essays on Law and Morality (2nd edn, 1979) $210 \mathrm{ff}$.

${ }^{28}$ Lon Fuller, In the Morality of Law (rev edn, 1969) $197 \mathrm{ff}$.

${ }^{29}$ Ronald Dworkin, A Matter of Principle (1985) 11-12, and Law's Empire (1986) at 206ff. 
the manner of a self-fulfilling prophecy, all utilize the common law context to explain and test their analysis.

Traditional Rechtsstaat, on the other hand, only exists where the State itself was the source of law. The idea that it might be separate from the State was inconceivable.

The Rechtsstaat means that law is the structure of the State, not an external limitation to it. Its voice is rationality and strict legality of administrative action, the supremacy of which over ordinary citizens was granted despite the recognition of rights and the autonomy of individuals. Liberty is a consequence not truly a premise of the law. ${ }^{30}$

After Nazi-ism, which proclaimed that it governed through laws, post-1945 Rechtsstaat embedded constitutional guarantees to protect the individual from an authoritarian State/sovereign. ${ }^{31}$ Having regard to modern Rechtsstaat and l'Etat de droit, one can conceive a broader remit that is more suited to implementing rule of law at the international level, particularly as regards the UN and both its external and internalized adoption of the principle. The German principle of Rechtsstaat focuses more on the regulation of the State through a constitutional order 'as a machine that would go of itself' ${ }^{32}$ While the judiciary play a role, the idea of modern Rechtsstaat is one where the relevant principles, discussed below, direct the State or, in this case, an international organization, so as to create a constitutional structure that fosters support from those affected by its exercise of powerthis represents a better framework for the rule of law in the context of the UN's humanitarian operations. $^{33}$

${ }^{30}$ Palombella (n 14) 11, see also 10-12, 14-17.

${ }^{31}$ See Krygier (n 3) 783, on Germany’s 1949 Grundgesetz: ‘Art 1, Human dignity shall be inviolable. To respect it and protect it shall be the duty of all state authority'. See also, Palombella (n 14) 25-26, 31.

${ }^{32}$ See Loughlin (n 3) 336, citing Michael Kammen, A Machine That Would Go of Itself: The Constitution in American Culture (1987).

${ }^{33}$ See Loughlin (n 3 ) 336-41; and Carré de Malberg (n 22) 492: 'Le régime de l'Etat de droit est un système de limitation, non seulement des autorités administratives, mais aussi du Corps legislatif'. Loughlin, (n 3 ) 319, suggests that Rechtsstaat could promote the individual's complete development; and see Harlow (n 14) 192, on how French administrative law better encapsulates rule of law at the international level for the UN. 
Alvare $^{34}$ is equally helpful in this regard, recognizing that rule of law at the national level is not directly applicable to rule of law on the international plane, and that an even clearer distinction within that plane between States and international organizations is required. With respect to international organizations, Bingham's Elements of the Rule of Law (4), (5), and (6), cited by Alvarez, ${ }^{35}$ would seem most appropriate as regards its application to humanitarian operations:

(4) the good faith exercise of power in accordance with purpose for which powers were conferred, without exceeding the limits of such powers;

(5) protection of fundamental human rights (including nullum crimen sine lege, the right to fair trial, and to liberty, security, and property); and

(6) access to other means to resolve civil disputes without prohibitive cost or delay.

These elements, while drawn from the common law conceptualisation, are not judge-centric and look to the organization to establish a rule of law process for its operations that will lead to a rule of law end-state. ${ }^{36}$ In sum, both the common law rule of law tradition and modern Rechtsstaat are core to rule of law in the UN. All references to 'rule of law' below should be understood to comprise both these meanings unless otherwise stated.

\subsection{Content and context}

This combined conception of rule of law better fits the approach to the principle for the UN, but its content still needs to be considered as well as the context of several similar frameworks often used in relation to the organization: good governance, due process, and global administrative law. There is a clear overlap between these ideas and also a lack of

\footnotetext{
${ }^{34}$ See Alvarez (n 12).

${ }^{35}$ ibid 9, citing Bingham (n 18).

${ }^{36}$ While Alvarez (n 12) says that he is trying to move from just conforming to a domestic rule of law mapping exercise to the international sphere for international organizations (at $15,25,29-30)$, there is still a strong sense of rule of law founded on judicial and legislative propriety (31ff), rather than seeing it as a comprehensive mechanism for achieving a society that fulfils rule of law standards, one which includes legislative and quasi-judicial elements, but which is broader. See Krygier (n 3) 785-86. On the dangers of juridification generally, see Harlow (n 14) $211 \mathrm{ff}$. See also part 4 below.
} 
precision in their meaning. The resulting merging of ideas does not facilitate clarity of analysis and application.

Starting with rule of law itself, as has been seen in the discussion of the common and civil law understandings, at its most formal and limited, it reflects the position that the State is governed by laws rather than by whim or diktat - a procedural/thin conception. ${ }^{37}$ It simply requires a procedure by which laws are made and a system of courts to implement them. However, does it entail the idea that laws should protect the individual from the $\operatorname{State}^{38}$ and, further, does it also include the broader conceptions of civil, political, economic, social, and cultural rights and development? ${ }^{39}$ For the purposes of this article, this constitutes the essence of the so-called procedural-substantive and 'thin-thick' debate(s). ${ }^{40}$ As will be seen, rule of law within the UN has to be understood as thick, simply because the thin

${ }^{37}$ On the full meaning of Rechtsstaatsprinzip/Rechtsstaatlichkeit within post-1945 German jurisprudence, see Loughlin (n 3) fn 5, citing Katharina Sobota, Das Prinzip Rechtsstaat (1997) 471-526, who identifies 142 different characteristics.

${ }^{38}$ See the UK's then House of Lords in Jackson and others (Appellants) v Her Majesty's Attorney General (Respondent) [2005] UKHL 56: '159. The courts will treat with particular suspicion (and might even reject) any attempt to subvert the rule of law by removing governmental action affecting the rights of the individual from all judicial scrutiny'.

${ }^{39}$ See eg Colombian Constitution of 1991, art 1, which refers to estado social de derecho, a phrase that has allowed the Constitutional Court to promote a progressive understanding of, inter alia, the rights of IDPs in Colombia with which UNHCR has actively engaged. See Decision T-025 (Republic of Colombia Constitutional Court, Third Review Chamber, Bogotá DC, 22 January 2004).

${ }^{40}$ Proceduralists, such as Raz (n 27210 and Dicey and Wade (n 24, require that laws are created in certain ways, that they meet certain formalities. Those who support more substantive interpretations of the rule of law require that laws meet a certain quality threshold, see the discussion of this position by Dworkin (n 29, where his communities of principle necessarily assume that law requires more than a mere rulebook test. Fuller, (n 28 $197 \mathrm{ff}$, attempts to inculcate moral standards into a proceduralist approach through his eight principles of legality. NB. the procedural element has to form part of the substantive concept if the laws as a whole are to conform to a rule of law society, compare Loughlin (n 3) 33335; and Harlow (n 14) 192. On this understanding, the procedural element is a necessary but insufficient step in the process. 
understanding makes little or no sense with respect to the function and capacities of the organization.

Hovell has analysed due process within the $\mathrm{UN}^{41}$ and her understanding embraces similar values to substantive/thick rule of law as explained in this article. ${ }^{42}$ In addition, the UN itself often refers to rule of law and good governance as though they are an inseparable pair, especially the World Bank and the International Monetary Fund. ${ }^{43}$ The danger is that rule of law is seen as merely a subset of good governance, an even more ephemeral, imprecise, and indeterminate concept. Nevertheless, if the good governance arguments emphasize that rule of law is more than just the judicial regulation of States and the UN, and that the principle should be at the heart of how operations should be run, then the juncture can promote a fuller understanding. Global administrative law also draws on rule of law. Indeed, administrative law generally is the locus for applying rule of law principles to administrative and governmental actors, so it should be no surprise that there is this interplay with respect to UN operations and UN interoperability. ${ }^{44}$

As Harlow showed, while distinctions may be drawn between global administrative law, good governance, due process, and rule of law, they all interact and cannot be neatly separated out. On the other hand, this article focuses on rule of law because the UN has adopted that particular principle as a framework for its activities. ${ }^{45}$ The problem with a lot of the academic discussion of rule of law for the $\mathrm{UN}$ or, for that matter, good governance, due

${ }^{41}$ Hovell (n 17). On the overlap between rule of law and due process, see Harlow (n 14) 204-07.

${ }^{42}$ See Hovell (n 17) 3, 17.

${ }^{43}$ See eg World Bank, 'World Development Report 2017: Governance and the Law' 83: 'It has long been established that the rule of law - which at its core requires that government officials and citizens be bound by and act consistently with the law - is the very basis of the good governance needed to realize full social and economic potential'. See also $<$ https://www.un.org/ruleoflaw/thematic-areas/governance/good-governance/ $>$. It is worth noting that rule of law is often seen as the 'junior partner' in this relationship.

${ }^{44}$ See Harlow (n 14) 191. As such, the interplay of both these ideas is to the fore in part 4, below, on rule of law as applying to international organizations.

${ }^{45}$ See 2004 Report (n 1); and 2012 High Level Meeting (n 2). 
process, and global administrative law, is that it is often inward-looking, ${ }^{46}$ about rule of law for its own sake, whereas this article explores the qualities and characteristics of rule of law for international organizations and how it might enhance operationalization, including interoperability. Discussion of rule of law should be about process and result, about what it might achieve, not simply about its use as a measuring tool for compliance and accountability.

\section{RULE OF LAW AT THE UN}

As mentioned, ${ }^{47}$ the Secretary-General's 2004 Report on the rule of law and transitional justice in conflict and post-conflict societies established how the organization was to understand the principle. ${ }^{48}$ In 2008 , there was a subsequent report of the Secretary-General on the rule of law at the national and international levels. ${ }^{49}$ It provided an inventory of the $\mathrm{UN}$ activities in the subject area at that time and it ran to 143 pages. The range was spectacular and was indicative of how the 2004 description was interpreted in different parts

${ }^{46}$ Compare Harlow (n 14), whose article challenges the very idea of unthinkingly applying global administrative law in the international sphere.

${ }^{47}$ See 2004 Report (n 1).

${ }^{48}$ Compare World Conference on Human Rights (Vienna, June 1993) UN doc A/CONF.157/23 (12 July 1993) paras 66 and 67, where what would be OHCHR was given the technical assistance mandate for rule of law: '67. Special emphasis should be given to measures to assist in the strengthening and building of institutions relating to human rights, strengthening of a pluralistic civil society and the protection of groups which have been rendered vulnerable. In this context, assistance provided upon the request of Governments for the conduct of free and fair elections, including assistance in the human rights aspects of elections and public information about elections, is of particular importance. Equally important is the assistance to be given to the strengthening of the rule of law, the promotion of freedom of expression and the administration of justice, and to the real and effective participation of the people in the decision-making processes' (emphasis added).

While this pre-dates the 2004 Report, it did not lead to any organizational adoption of rule of law akin to the Vienna Declaration with respect to human rights. See also McCorquodale (n 1) $284-88$.

${ }^{49}$ See (n 2). 
of the organization, but the report did not cover whether the activities were successful. ${ }^{50}$ Following a multi-actor meeting in $2011,{ }^{51}$ the High Level Meeting of the General Assembly adopted its 2012 Declaration on the Rule of Law at the National and International Levels. ${ }^{52}$ Member States affirmed that 'all persons, institutions [including the UN] and entities, public and private, including the State itself, are accountable to just, fair and equitable laws and are entitled without any discrimination to equal protection of the law', a very substantive conception. The 2015 Sustainable Development Goals ${ }^{53}$ (SDGs) ultimately did not expressly include rule of law, but the targets for Goal 16 refer to rule of law at national and international levels. The New York Declaration on addressing large movements of refugees and migrants refers to rule of law as a necessary response of governments. ${ }^{54}$ Thus, rule of law has been embedded in the way the organization approaches its activities, both internally and with States; that said, different parts of the organization, depending on their specific mandates, can implement rule of law principles in their own particular way, something that allows for flexibility but that might not ensure predictability across the organization or facilitate inter-agency dialogue.

The thesis of this article is that only a substantive/thick, rights-based approach to rule of law can properly reflect the community and culture of the UN, one that promotes the operationalization of interoperability within the organization.

${ }^{50}$ See David Marshall, 'Reboot Required: The United Nations Engagement in Rule of Law Reform in Postconflict and Fragile States' in Marshall (ed) (n 4) $85 \mathrm{ff}$.

51 'Supporting Complementarity at the National Level: An Integrated Approach to the Rule of Law' (7-9 December 2011). See also Secretary-General's Report, 'Delivering Justice: Programme of Action to Strengthen the Rule of Law at the National and International Levels' UN doc A/66/749 (16 March 2012).

${ }^{52}$ See (n 2).

${ }^{53}$ The Sustainable Development Goals (SDGs), 'Transforming our World: The 2030 Agenda for Sustainable Development' GA res 70/1 (25 September 2015): 'Goal 16 of the Sustainable Development Goals is dedicated to the promotion of peaceful and inclusive societies for sustainable development, the provision of access to justice for all, and building effective, accountable institutions at all levels' ... '16.3 Promote the rule of law at the national and international levels and ensure equal access to justice for all'. Also see World Bank (n 43. ${ }^{54}$ See New York Declaration (n 5) paras 12, 43, 64 and Annex 1, para 13(d). 
3.1 The Understanding, scope and operationalization of the rule of law in the UN

Since the Secretary-General's 2004 Report, the UN has utilized the concept of rule of law. However, there has been little conceptual thinking regarding the content and implementation required for it to enhance State capacity, protect and empower individuals and groups, and ensure effective operationalization by and within the organization. ${ }^{55}$ This section of the article examines the scope of rule of law in the UN, before going on to explore how the organization has adopted rule of law in practice, often in relation to the challenging environment of displacement to highlight its relevance to all UN operations, its applicability, and also its complexities.

This requires an appreciation of what interoperability means in the UN. ${ }^{56}$ At one level, it is about sharing resources on the ground. ${ }^{57}$ Under 'Delivering as One', ${ }^{58}$ the UN as a whole aimed to provide a coherent and co-ordinated response to crises, so interoperability was central to this plan. Under rule of law, the broader idea of co-operating with States and enhancing their capacity is core, as well as UN actors working together - central to the 2012 Declaration. ${ }^{59}$ For UNHCR, with its unique protection mandate, interoperability in the context of displacement focuses on co-ordinating activities within the UN for the benefit of

${ }^{55}$ Compare Alvarez (n 12). See also 'UNHCR Recommendations for Greece in 2017' $<$ http://www.unhcr.org/58d8e8e64.pdf $>$.

${ }^{56}$ The Oxford English Dictionary defines it as: 'The ability of two or more pieces of equipment esp. military equipment, to operate in conjunction' (first used 1965), 'interoperability, n.' OED Online (June 2017), Oxford University Press $<$ http://0www.oed.com.serlib0.essex.ac.uk/view/Entry/248420?redirectedFrom=interoperability\&> accessed 29 October 2017.

${ }^{57}$ However, given the entirely non-political and humanitarian character of UNHCR's work under para 2, Statute (n 6), should it ever lend vehicles to DPA or DPKO?

${ }^{58}$ See 'Independent evaluation of lessons learned from "Delivering as one", UNGA res 66/859 (26 June 2012) <http://www.un.org/en/ga/deliveringasone/>. DaO is not as prominent in the UN as it was in 2013-16, its thrust having been subsumed in the SecretaryGeneral's reform initiative.

${ }^{59}$ See (n 2). 
individuals of concern, although, on the ground, it works with external humanitarian agencies as well.

3.2 The concept of rule of law in the UN and its scope of application

The UN has adopted its own practice and policy with respect to rule of law. While international and domestic interpretations interact with how the UN utilizes the rule of law principle, it has adopted a discrete understanding that could potentially underpin effective operationalization of interoperability. The UN is not one monolithic structure marching to the beat of a single drum and its adoption of rule of law might facilitate an approach that allows it to 'deliver as one' to enhance State capacity and to empower individuals and groups of concern. ${ }^{60}$ It might also enhance 'legal certainty, avoidance of arbitrariness and procedural and legal transparency' within the organization. ${ }^{61}$

For all this to be achieved, the concept of rule of law for the UN needs to be established and the scope of activities to which the organization must adopt a rule of law approach then needs to be set out.

3.2.1 Understanding how rule of law might be conceived for the UN: rule of law and Rechtsstaat

As indicated above, rule of law has been much explored by legal theorists, constitutional lawyers, and, more recently, international lawyers, including how it might be understood within the UN. ${ }^{62}$ Given the 2004 Report and its express reference to the UN's concept of the

${ }^{60}$ Quaere, McCorquodale (n 1) 278, who sees rule of law as refuting the idea that international law is simply 'politics or lacking normative legality'. His article produces a list of factors appropriate to the international legal environment, but the starting point for his analysis, the High Level Meeting of 2012, was never just about what international rule of law is; but also about how rule of law can be used to achieve a goal, a rule of law society, through a process of rule of law implementations. As such, his new definition is of little use to the UN on the ground, working with States, individuals, and a co-ordinated organization providing coherent programmes.

${ }^{61}$ Compare Andrea Bianchi, 'Ad-hocism and the Rule of Law' (2002) 13 European Journal of International Law 263.

${ }^{62}$ For a view of the possible content of rule of law within the UN, see Alvarez (n 12). See also Watts (n 15); Chesterman (n 18); Kenneth J Keith, ‘The International Rule of Law' 
rule of law as being a principle under which laws are 'consistent with international human rights norms and standards', one might assume it must be understood to embrace the 'thick'/substantive interpretation, one that is invested with the attributes of Preamble to the Charter and its purposes and principles. ${ }^{63}$ That, though, would be simply to restate the 2004 Report in other terms. For the purposes of this article, it is necessary to briefly consider how rule of law theory would accommodate the UN, but equally how rule of law in the domestic and international spheres cannot readily be transposed onto the organization: one might need to adopt a 'soft' interpretation and application of rule of law for the UN.

The appropriate theoretical framework for rule of law as regards the UN depends on how one applies rule of law principles to different entities. In the case of the UN, its rule of law must reflect Charter values; moreover, the institution's subsequent elaboration of a rule of law framework is one that is developed through and overseen by the General Assembly of the Member States. ${ }^{64}$ Equally, since the foundational documents lay down the institution's powers, references back to the Charter and to human rights more generally in UN rule of law

(2015) 28 Leiden Journal of International Law 403; PS Rao, 'The Nature and Function of International Law: an Evolving Rule of International Law' (2015) 55 Indian Journal of International Law 459; Machiko Kanetake, 'The Interfaces between the National and International Rule of Law: a Framework Paper' in Kanetake and Nollkaemper (eds) (n 17) 11; and Hovell (n 17).

${ }^{63}$ Charter of the UN (26 June 1945): 'We the Peoples of the United Nations determined ... to reaffirm faith in fundamental human rights, in the dignity and worth of the human person, in the equal rights of men and women and of nations large and small, ... Article 1. The Purposes of the United Nations are: ... 3. To achieve international cooperation in solving international problems of an economic, social, cultural, or humanitarian character, and in promoting and encouraging respect for human rights and for fundamental freedoms for all without distinction as to race, sex, language, or religion; ...'. James Goldston, 'New Rules for the Rule of Law' in Marshall (ed) (n 4) 19, points out that the September 2000 draft Millennium Development Goals for all States also connected rule of law with international human rights, but the final 2001 version of the MDGs removed all references to rule of law and human rights. The SDGs (n 53 include a reference in the targets for Goal 16.

${ }^{64}$ See 2005 World Summit Outcome, GA res 60/1 (24 October 2005) para 119. 
are not, in this case, indicative of a circular argument, but recognize the context of rule of law for an international organization - its community and culture. ${ }^{65}$

While a procedural understanding of rule of law might be adequate for certain international organizations, not even Fuller's principles of legality ${ }^{66}$ could properly encompass rule of law for the UN, given that the Charter and subsequent developments within the organization as to the remit of human rights guarantees reference rule of law. ${ }^{67}$ As the Preamble to the Universal Declaration of Human Rights 1948 sets out, the human rights in the Declaration 'should be protected by the rule of law'. ${ }^{68}$ Whether one terms it

${ }^{65}$ See subsequent discussion of the accountability of the UN as part of rule of law, part 4; see Case C-402/05, P, Kadi and Al Barakaat International Foundation v Council of the EU and Commission of the EC [2008] ECR I-06351; and Al-Dulimi and Montana Management Inc v Switzerland App No 5809/08 (ECtHR, Grand Chamber, 21 June 2016) paras 145-49, where the Grand Chamber held that the Security Council decisions that affect individuals must be subject to a review based on human rights standards: 'As a result, in view of the seriousness of the consequences for the Convention rights of those persons, where a resolution such as that in the present case, namely [Security Council] Resolution 1483, does not contain any clear or explicit wording excluding the possibility of judicial supervision of the measures taken for its implementation, it must always be understood as authorising the courts of the respondent State to exercise sufficient scrutiny so that any arbitrariness can be avoided. By limiting that scrutiny to arbitrariness, the Court takes account of the nature and purpose of the measures provided for by the Resolution in question, in order to strike a fair balance between the necessity of ensuring respect for human rights and the imperatives of the protection of international peace and security'. European Court of Human Rights decisions available online at $<$ http://hudoc.echr.coe.int/eng\#\{"documentcollectionid2":["JUDGMENTS","DECISIONS", "ADVISORYOPINIONS"] $\}>$.

${ }^{66}$ See (n 28 esp 197-204. The use of internal morality by Fuller to support a proceduralist stance on rule of law is akin to eating one's cake while denying it was cake. Also see Loughlin (n 3) 333-35.

${ }^{67}$ See esp World Conference on Human Rights, Preamble (n 48.

${ }^{68}$ GA res 217A (III) (10 December 1948) (UDHR 1948). 
substantive, thick, or the middle way, ${ }^{69}$ rule of law within the UN is more than simply establishing procedures by which to create law. However, while rule of law for the UN must incorporate human rights values in terms of its own actions, in the way it builds capacity within States and enhances the protection of individuals, it is essential to avoid equating rule of law with international human rights law as that would negate rule of law as a separate framework and process. Rule of law and international human rights law are mutually reinforcing. ${ }^{70}$ When one has regard to the full scope of civil, political, economic, social, and cultural rights, which address a range of issues richer than a thick interpretation of rule of law, those rights set out the aspirations of a comprehensively enabling society where rule of law is intrinsic and embedded. Yet, rule of law/Rechtsstaat encompasses ideas about the governance, structures, procedures, and processes of States and international organizations, which go beyond the remit of international human rights law. It is why the Preamble to the UDHR 1948 talks of rule of law protecting human rights - in this context, the later 20th century 'Rechtsstaat' better expresses the understanding than the common law 'rule of law'. ${ }^{71} \mathrm{UN}$ rule of law facilitates access to human rights - it is rights-based and rights enhancing.

An application of the rule of law that is limited to policing, justice, and corrections can still adopt a human rights infused approach, just one based on a limited set of human rights. Indeed, as Marshall makes clear, a lot of UN operations have seen rule of law in these

${ }^{69}$ See Craig (n 21).

${ }^{70}$ Compare Krivenko (n 20) 293-96, who seems, in part, to treat this as troubling when, in fact, both rule of law and international human rights law are interdependent with discrete constraints on the State at the domestic and international levels. See also Craig (n 21) 487.

${ }^{71}$ See UDHR 1948. Also see Sobota (n 37, who explains that the principle of Rechtsstaat incorporates eg Effektiver Rechtsschutz (effective rights protection), Willkürverbot (prohibition of arbitrariness), Kommunale Selbstverwaltung (local self-government), Verantwortlichkeit (accountability), and Verhältnismäßigkeit (proportionality). Compare Palombella (n 14), who contrasts common law rule of law with 19th century Rechtsstaat. Here, we use Rechtsstaat as it has developed since 1945, which draws on common law ideas of it restraining the State. 
terms. ${ }^{72}$ However, that does not mean it is the correct approach or that it should ever be so conceived. To be sure, policing, justice, and corrections are part of rule of law, but they are not the full story. ${ }^{73}$ As Alston ${ }^{74}$ makes clear, it is important that the UN's use of rule of law language is always rooted in international human rights law: ${ }^{75}$

The answer is that rights language provides a context and a framework, invokes states' legal obligations, underscores that certain values are non-negotiable, brings a degree of normative certainty, and makes use of the agreed interpretations of rights that have emerged from decades of reflection, discussion and adjudication. Most important, rights language recognizes the dignity and agency of all individuals and is intentionally empowering.

Thus, the adoption of a rule of law approach by the UN must not become a way for States to attenuate their obligations under international human rights law by relying on the inherent

\footnotetext{
${ }^{72}$ Marshall (ed) (n 4). See also UNDP Human Development Report 1992, 31, Box 2.2, on an indicative checklist of political freedom including rule of law $<$ http://hdr.undp.org/sites/default/files/reports/221/hdr_1992_en_complete_nostats.pdf $>$. ${ }^{73}$ See Nigel D White, The Law of International Organisations (2nd edn, 2005) 23-25. ${ }^{74}$ See Philip Alston, 'The Two Words that Scare the World Bank' Washington Post (7 November 2014) <https://www.washingtonpost.com/opinions/philip-alston-the-world-banktreats-human-rights-as-unmentionable/2014/11/07/9091dafa-65da-11e4-9fdcd43b053ecb4d_story.html?utm_term=.fdb80825d395>, on the World Bank's reluctance to use human rights language while nevertheless calling 'for gender equity and access for the poor to food, shelter, clean water, sanitation, health care, education and jobs'. Rule of law language equally risks masking the true nature of the State's obligation ie that displaced persons, like everyone else within the territory and jurisdiction of the State, have rights. Alston is currently the UN Special Rapporteur on extreme poverty and human rights. ${ }^{75}$ See also the Sixth Committee, 'The Rule of Law at the National and International Levels' UN doc A/C.6/69/L.20 (11 November 2014) Preamble, para 3: 'Reaffirming that human rights, the rule of law and democracy are interlinked and mutually reinforcing and that they belong to the universal and indivisible core values and principles of the United Nations'.
} 
vagueness of the principle. ${ }^{76}$ As explained by the Special Rapporteur on the promotion of truth, justice, reparation, and guarantees of non-recurrence: ${ }^{77}$

the United Nations system, throughout all its organs, has clearly opted for a rich understanding of the notion [of the rule of law] that refers to human rights, including a wide catalogue of political rights and, among them, democratic rights, the promotion of development and good governance.

In November 2013, the Secretary-General launched the Human Rights Up Front initiative that aims to institute a cultural change within the UN so that the rights and protection of

${ }^{76}$ See Goldston (n 63 5, on how the UN might have endorsed such an approach by States. On 'thin' and 'thick' values for the rule of law, see Bingham (n 18) 66-67, and Chesterman (n 18); along with Craig (n 21). See also Randall Peerenboom, 'Human Rights and Rule of Law: What's the Relationship?' Research Paper 05-31 (University of California, Los Angeles School of Law, Public Law \& Legal Theory Research Paper Series), which cites how Singapore uses rule of law discourse to justify limits on freedom of religion under the Maintenance of Religious Harmony Act (ch 167A), while its critics call for a more robust rule of law to challenge the government's limitations.

${ }^{77}$ See Report of the Special Rapporteur to the General Assembly, UN doc A/67/368 (13 September 2012) para 12. He goes on to refer to the Human Rights Council emphasising 'the relevance of rule of law to peace, development and social cohesion (premised on gender equality and the elimination of all forms of discrimination)', para 13. If the objective is to engage with rule of law in order to promote solutions to protracted crises, those factors are central to sustainability. See also his recommendation, para 82: 'The Special Rapporteur wishes to highlight that country experiences of these measures suggest that a purely formalist[/proceduralist/thin] understanding of the rule of law has been insufficient to prevent violations and that the notion of the rule of law to which transitional justice bodies have sought to contribute is a robust one that links it with human rights, governance and development and that asserts its relevance for peace and social cohesion, including gender equality and the absence of discrimination on any grounds' (emphasis added). The report also makes clear that rule of law in its substantive/thick conception goes towards maintaining international peace and security. See also, Palombella (n 14) 29-30. 
civilians are a core responsibility across the organization. ${ }^{78}$ It therefore seems likely that this initiative must also apply to the UN's approach to rule of law. For instance, were the UN to adopt a strictly proceduralist approach to rule of law for post-conflict States where it operates, it would be satisfied if the State applied laws in its dealings with individuals and institutions in the State, regardless of whether those laws met international human rights norms. With a proceduralist stance, the State might have to meet those aspects of international human rights that are peremptory norms, but even this would not satisfy the UN's requirement of respect for human rights and fundamental freedoms for all without distinction, promoted since $1945 .^{79}$

If the substantive/thick approach cannot be denied, its scope still needs to be established to show that rule of law goes beyond those rights that encompass access to justice and procedural fairness to include economic, social, and cultural rights, and development. For that to be the case for the UN, rule of law must embrace: (a) the individual at the centre of planning and implementation, (b) the indivisibility of all human rights, and (c) a focus on outcomes rather than institutions. If this can be shown to apply in the complicated context of displacement, that suggests its relevance to all UN operations.

\footnotetext{
${ }^{78}$ See Secretary-General Ban Ki-moon, 'Renewing our commitment to the peoples and purposes of the United Nations' (22 November 2013) $<$ http://www.un.org/apps/news/infocus/sgspeeches/statments_full.asp?statID=2068\#.VZ010 HhUi5c>; see also UN Deputy Secretary-General Jan Eliasson, 'Deputy Secretary-General's Remarks at Briefing of the General Assembly on Rights Up Front' (17 December 2013) $<$ https://www.un.org/sg/en/content/dsg/statement/2013-12-17/deputy-secretary-generalsremarks-briefing-general-assembly-rights $>$.

${ }^{79}$ If practice can be used to indicate policy, then the UN operations in Cambodia and East Timor (now Timor Leste) led to the ratification of a far broader range of human rights obligations by those States than is normal in the region.
} 
3.2.2 The operationalization of a human rights content to UN rule of law

\section{(a) Individual focus}

According to Waldron, ${ }^{80}$ rule of law in international law is primarily focused on the individual. Given that the UN understanding of rule of law embraces human rights, it must incorporate all individuals within the jurisdiction and territory of the State, regardless of nationality or even lack thereof. Clearly, IDPs as nationals of the State should be included, but rule of law must also extend to refugees, asylum seekers, returnees, and stateless persons residing in the State. Dworkin's community of principle 'commands that no-one be left out' and it 'assumes that each person is as worthy as any other'. ${ }^{81}$ One can read into this the protection role and the supervisory function in relation to States' duties that are given to UNHCR by its Statute and the 1951 Convention with respect to refugees, asylum seekers, and returnees. ${ }^{82}$ UNHCR has the unique mandate to provide international protection to refugees. Moreover, that mandate means that it has a direct relationship with individuals of concern, something not common for UN agencies. ${ }^{83}$ The increased restrictions on the sovereignty of States since 1945, vis à vis the treatment of persons on their territory as a consequence of international human rights law, provides the UN with a similar role as regards IDPs. ${ }^{84}$ If that displacement focused analysis is accepted, then it highlights the

${ }^{80}$ Jeremy Waldron, 'Are Sovereigns Entitled to the Benefit of the International Rule of Law?' (2011) 22 European Journal of International Law 315, 325ff, although he does acknowledge its limitations. Also see Hovell (n 17) 22; and the Separate Opinion of Judge Cançado Trindade in Accordance with International Law of the Unilateral Declaration of Independence in Respect of Kosovo, Advisory Opinion, ICJ Rep 2010, 403, esp paras 53-96.

${ }^{81}$ Dworkin (n 29213.

${ }^{82}$ UNHCR Statute, paras 1 and 8a, 1951 Convention, arts 35 and 36, and 1967 Protocol, art II, all (n 6); and Türk and Garlick (n 5) 659ff.

${ }^{83}$ Most UN agencies, such as UNDP and UNICEF, work with governments to promote protection of individuals, not with the individuals, whereas you will see refugees in UNHCR offices.

${ }^{84}$ See generally on these matters, Samantha Besson, 'Sovereignty, International Law and Democracy’ (2011) 22 European Journal of International Law 373, 381-84; and Catherine Dauvergne, 'Sovereignty, Migration and the Rule of Law in Global Times' (2004) 67 Modern Law Review 588. In an era of increasing disaster driven displacement, one can also 
substantive/thick conception of rule of law for the UN, this fits with the principle in international law and it would facilitate operationalization by the UN at the national level.

\section{(b) The indivisibility of human rights}

Since 1993, human rights have been recognized to be:

universal, indivisible and interdependent and interrelated. The international community must treat human rights globally in a fair and equal manner, on the same footing, and with the same emphasis. ${ }^{85}$

Thus, given that rule of law has to be applied in such a way that it protects international human rights norms and standards, it must embrace not only civil and political rights, but also economic, social, and cultural rights, and it must apply to everyone within a State's jurisdiction.

make an argument for UNHCR's engagement in response to the protection gaps in this area as they impact on individuals of concern to the organization. See also by way of corollary, $\mathrm{S}$ Ratner, The Thin Justice of International Law: A Moral Reckoning of the Law of Nations (2015). It is interesting that Ratner uses how far a norm respects basic human rights as one of his twin pillars by which to assess the justice of international law. He also recognizes the weakness of institutions in international law by comparison with those in domestic legal systems, see 5, 76, 84, and esp ch 7.

${ }^{85}$ World Conference on Human Rights, para 5 (n 48. The General Assembly in 2013 went even further in its 'Outcome Document for the Special Event of 25 September 2013' 3: 'We are resolved that the post-2015 development agenda should reinforce the international community's commitment to poverty eradication and sustainable development. ... It should also promote peace and security, democratic governance, the rule of law, gender equality and human rights for all' $<$ http://www.un.org/millenniumgoals/pdf/Outcome\%20documentMDG.pdf $>$. See also GA res 67/1 (n 2) para 7; and Julinda Beqiraj and Lawrence McNamara, 'The Rule of Law and Access to Justice in the Post-2015 Development Agenda: Moving Forward but Stepping Back’ Bingham Centre Working Paper 2014/04 (August 2014). 
With respect to IDPs, the Guiding Principles on Internal Displacement ${ }^{86}$ already affirm their entitlement to such rights during their displacement. However, for refugees, the rule of law approach would strengthen their rights as set out in the 1951 Convention, because, although it was the first multilateral treaty to provide a range of legally binding economic, social, and cultural rights, ${ }^{87}$ it did not confer all those rights on every 'refugee'. ${ }^{88}$ Since refugee status is declaratory rather than constitutive, those rights accorded simply to 'refugees', such as non-refoulement, must be available to all who have applied for refugee status, that is, all asylum seekers, up until it is determined that they do not fall within the Convention. However, other rights, such as article 17, dealing with employment, are only accorded to 'refugees lawfully staying in the territory', and can, therefore, only be available to refugees/asylum seekers further along in the process of status determination. A rule of law approach that is consistent with international human rights norms and standards, such as article 6 International Covenant on Economic, Social and Cultural Rights, ${ }^{89}$ would allow all displaced persons to benefit from those norms and standards without the distinctions found in the 1951 Convention. Furthermore, as is considered below, the 'indivisible human rights' focus undermines a strict humanitarian-development dichotomy within the UN. ${ }^{90}$

\section{(c) Justice outcomes, not institution building}

In the early days of the UN's adoption of rule of law, policing, justice, and corrections were the objectives, and the focus had been on institution building. To an extent, this remains a necessary part of implementing rule of law, particularly in post-conflict societies, ${ }^{91}$ but it

\footnotetext{
${ }^{86}$ UN doc E/CN.4/1998/53/Add.2 (1998), Principles 18, 22b, and 23, along with the Introduction, para 1.
}

${ }^{87}$ See Michelle Foster, International Refugee Law and Socio-Economic Rights: Refuge from Deprivation (2007); Alice Edwards, 'Human Rights, Refugees, and The Right "To Enjoy" Asylum’ (2005) 17 International Journal of Refugee Law 293.

${ }^{88}$ See 1951 Convention (n 6) eg the right to association in art 15 , or the right to wageearning employment in art 17.

\section{${ }^{89} 993$ UNTS 3.}

${ }^{90}$ See The humanitarian/development (false) dichotomy, part 3.3.2 (b) below.

${ }^{91}$ To the extent that they show that no-one in the society is above the law, see Pablo de Greiff, cited by Goldston (n 6313. 
cannot be the measure of a successful operation. ${ }^{92}$ The human rights focus entails that rule of law should deal with justice issues and lead to justice outcomes, that is, where success is measured by the improvements experienced by the population as a whole, including all displaced persons. ${ }^{93}$

129. Thus, it clearly ensues from these and the previous Reports that, to start with, the main concern of the UN Secretary-General and UNMIK was with the safety and the conditions of living of the population. It then turned to public institution-building. International administration of territory does not appear as an end in itself - not international administration of territory for territorial administration's sake — but rather as a means to an end, namely, to secure the well-being of the 'people' or the 'population', and the inhabitants living under the rule of law in a democratic society. ${ }^{94}$

92 See Krygier (n 3) 784-85. See also, Marshall (ed) (n 4), especially Louis-Alexandre Berg, Deborah Isser, and Doug Porter, 'Beyond Deficit and Dysfunction: Three Questions Toward Just Development in Fragile and Conflict-Affected Settings' 266ff. It is worth noting here that there are very few references to human rights in this chapter, possibly because the authors are from the World Bank - compare Alston (n 74; Galit A Sarfaty, Values in Translation: Human Rights and the Culture of the World Bank (2012); and Jan Klabbers, 'The Transformation of International Organizations Law' (2015) 26 European Journal of International Law 9, 78. For a much deeper analysis of this problem, see Alvaro Santos, 'The World Bank's Uses of the "Rule of Law" Promise in Economic Development' in David M Trubek and Alvaro Santos (eds), The New Law and Economic Development: A Critical Appraisal (2006) 253, 270-71.

${ }^{93}$ The plight of refugees starts in the source State, but continues into the State of refuge. The refuge State has to ensure that no-one is left behind and that applies to displaced persons within its borders too, see SDGs (n 53 paras 23 and 29 of the Resolution. See also Harlow (n 14) 206 , on how due process permits participation in decision-making.

${ }^{94}$ Cançado Trindade J (n 80 (emphasis added). And see Krygier (n 3) 786. 
The thick, substantive approach to rule of law in the UN is rights-based, but it also enhances rights by facilitating access to justice. ${ }^{95}$

3.3 The consequences of operationalizing the rule of law in the UN

It bears reiteration that the $\mathrm{UN}$ is not one monolithic entity that marches to the beat of a single drum. Hence, interoperability within the UN could form the basis for successful operationalization. ${ }^{96}$

\subsubsection{Different UN actors, different understandings}

The Secretary-General's 2004 Report description of rule of law has been adopted by the various actors within the UN, but on the basis of their individual mandates. Even at the level of inter-agency co-ordination, there are two UN bodies: the Global Focal Point on Police, Justice and Corrections (GFP) ${ }^{97}$ and the Rule of Law Co-ordination and Resources Group (RoLCRG). ${ }^{98}$ The GFP consists of: the Department of Peacekeeping Operations (DPKO), the UN Development Programme (UNDP), the Office of the High Commissioner for Human Rights (OHCHR), the UN Office on Drugs and Crime (UNODC), and UN Women. The GFP is led by UNDP and DPKO; it aims to strengthen rule of law in post-conflict and other crisis situations by delivering police, justice, and corrections assistance, as well as by deploying advisers, who deal with issues like detention, sexual and gender based violence (SGBV), or security. At the strategic level, the RoLCRG has a coordination function to

95 As Marshall, (n50 114, puts it, drawing on Rachel Kleinfeld, Advancing the Rule of Law Abroad: Next Generation Reform (2012), it is: "“power" and "culture", not laws and institutions [that] form the roots of a rule of law state'.

${ }^{96}$ See Secretary-General's Report, providing background and recommendations for the highlevel plenary meeting (n 5). See also Harlow (n 14) 210-11.

${ }^{97}$ See

$<\mathrm{http}$ ://www.undp.org/content/undp/en/home/ourwork/crisispreventionandrecovery/focus_ar eas/rule-of-law/global-focal-point-for-police--justice-and-corrections-/>.

${ }^{98}$ See $<$ http://www.unrol.org/article.aspx?article_id=6>. Strangely, the UN Policy on Integrated Assessment and Planning, approved by the Secretary-General in April 2013, does not mention rule of law, but it does refer to human rights. The 2014 Integrated Assessment and Planning Handbook on how to carry out the policy, however, refers extensively to rule of law. 
ensure coherence of rule of law within the UN; it includes a wider group of actors and has a much broader approach to rule of law than just securitization matters.

\subsubsection{Rule of law and forced displacement - testing the principle in extremis}

As stated, displacement provides a particularly challenging context for rule of law since it does not neatly fit the Westphalian model that traditionally frames international obligations and UN operations. It raises issues about the UN's approach to the 2004 Statement, the humanitarian/development dichotomy, and the links between protection and resolution of the displacement.

\section{(a) Displacement and the UN in the light of the 2004 Statement}

In the event of a mass displacement due to armed conflict, serious disturbances affecting public order, or some other humanitarian disaster, UNHCR has a mandate to protect refugees and asylum-seekers, to take the lead on the protection of conflict-IDPs, and to co-lead on shelter and camp co-ordination and camp management. ${ }^{99}$ At the onset of such an emergency, protection will consist of gaining access to displaced persons; safeguarding them from the effects of armed conflict or other generalized violence, including ensuring nonrefoulement, ${ }^{100}$ in particular, reducing the risk of SGBV, and providing emergency food and non-food items, including shelter; and establishing initial registration processes, as well as screening out those clearly excluded from refugee status. Such activities fall under both the narrow GFP and broad RoLCRG approaches to rule of law. The activities should involve the States affected and be co-ordinated with other UN bodies. Given that one of the other principal UN actors in such emergencies is DPKO, which heads rule of law in the organization, a rule of law analysis will enhance inter-agency co-operation.

Three elements of the Secretary-General's 2004 statement $^{101}$ are fundamental to rule of law as it might apply in situations of displacement: the equality of all; inclusive

\footnotetext{
${ }^{99}$ See UNHCR Statute (n 6); and <http://www.refworld.org/idps.html>.

${ }^{100}$ Compare 'Bangladesh presses Myanmar as Rohingya flee across border' (BBC News, 23 November 2016) <http:/www.bbc.com/news/world-asia-38083901>.

${ }^{101}$ See 2004 Report (n 1).
} 
approaches; ${ }^{102}$ and, because rule of law is both a process and an outcome for the State, it being solutions-focused. The three overlap and are complementary.

Equality combined with non-discriminatory practices in situations of displacement is important throughout a person's time as a refugee, asylum-seeker, or IDP. ${ }^{103}$ In terms of the exercise of civil and political, or economic, social, and cultural rights during the displacement, there must be equal access for everyone to justice, education, work, and shelter. Protection through proper policing and access to courts needs to be available alongside freedom to take up educational and employment opportunities. However, 'warehousing' of refugees by the State in remote parts of the territory undermines these opportunities and inclusivity generally, and calls into question how far the State is upholding rule of law.

In terms of inclusivity and the ultimate protection of a durable solution, that is, voluntary repatriation/return, resettlement/relocation, or local integration, the voices of displaced persons need to be heard. Where local integration is the response, refugees should also be able to participate, but when peace agreements and reparations are being negotiated in the State from which the refugees have fled, the views of those displaced across

\footnotetext{
${ }^{102}$ See Dworkin (n 29.
}

${ }^{103}$ Non-discriminatory practices mean that genuine differences have to be taken into account, so, even where IDPs are still in their State of nationality, the special consequences of their displacement must be borne in mind, see Elizabeth Ferris, 'The Dangers of Mainstreaming IDPs into Oblivion' (iDMC, 29 January 2015) <http://www.internaldisplacement.org/blog/2015/guest-blogger-elizabeth-ferris-describes-the-dangers-ofmainstreaming-idps-into-oblivion $>$. On the proper application of non-discrimination as between groups, see Geoff Gilbert, 'Jurisprudence of the European Court and Commission of Human Rights in 1999 and Minority Group', report to UN Working Group on Minorities E/CN.4/Sub.2/AC.5/2000/CRP.1 (May 2000), 'The Burgeoning Minority Rights Jurisprudence of the European Court of Human Rights' (2002) 24 Human Rights Quarterly 736, and 'Article 5' in Marc Weller (ed), The Rights of Minorities: A Commentary on the European Framework Convention for the Protection of National Minorities (2005) 156. Also, SDG 5.1 (n 53. 
international borders have to be accommodated. In Leopoldo Garcia Lucero v Chile, ${ }^{104}$ the Inter-American Commission on Human Rights held that the victim should be compensated for being forced into exile. ${ }^{105}$ The peace arrangement concluded between Mali and the Tuareg rebel movement on 20 June 2015 required a tripartite agreement including UNHCR, which represented the Malians who had crossed into neighbouring countries, so that stability can be restored. ${ }^{106}$

If equality and non-discrimination are primarily benefitting displaced persons in terms of rights during the displacement, inclusivity also benefits States, filtering down to

${ }^{104}$ Report No 23/11 Case 12.519 Merits, Leopoldo García Lucero and Next of Kin v Chile (23 March 2011), referred to the Inter-American Court of Human Rights on 20 September 2011. The Court declined to deal with the issues surrounding exile, only because it took place in 1975 before Chile accepted the jurisdiction of the Court on 21 August 1990, see García Lucero et al v Chile, Judgment (Preliminary Objection, Merits and Reparations) 28 August 2013, I/A Court HR, Series C No 267 (2013) paras 35-36 $<$ http://www.corteidh.or.cr/index.php/en/jurisprudencia $>$.

${ }^{105}$ For early examples of this, see Truce agreement, Bosnia and Herzegovina (17 July 1992) para 3: 'We agree that all refugees will be permitted to return to the places from which they have been expelled and that civilians who are caught up in, or trapped by the military situation will be given freedom of movement'; and Dar-Es-Salaam Declaration on Peace, Security, Democracy and Development in the Great Lakes Region (19-20 November 2004) para 69: 'Ensure that refugees and displaced persons, upon return to their areas of origin, recover their property with the assistance of the local traditional and administrative authorities'. The authors are grateful to Dr Tiina Pajuste of the Lauterpacht Centre for International Law, Cambridge, for these references.

${ }^{106}$ See $<$ http://www.loc.gov/lawweb/servlet/lloc_news?disp3_1205404475_text $>$ and $<$ http://www.insightonconflict.org/2014/07/road-peace-mali-political-roadblocksobstacles/>. See also the New York Declaration (n 5) Annex 1: Comprehensive refugee response framework, para 12(e); Jennifer Easterday, 'The Rule of Law at the National and International Levels in Post-Conflict Peace Agreements' in Kanetake and Nollkaemper (eds) (n 17) 390-92; and Roger Duthie (ed), Transitional Justice and Displacement (2012). Of course, anyone excluded under art $1 \mathrm{~F}$ of the 1951 Convention cannot be represented by UNHCR, although they are the sorts of person who may well have been senior members of rebel movements prior to displacement. 
benefit all persons in the territory. No-one would deny that hosting a displaced population is a burden on the State. ${ }^{107}$ Therefore, the State should include displaced persons in their development planning to ensure its own affairs are managed whilst meeting the needs of those displaced onto its territory; and responsibility sharing by the international community is required. The same is true in reverse for States in transition as the population who left during the conflict returns. ${ }^{108}$ These situations focus rule of law approaches on promoting solutions to displacement: if the individuals' rights are being met in a State where they are part of the development programme, that will facilitate their local integration, resettlement, or their capacity to return, and it will avoid the UN having to create a parallel State structure for them. If this is to work, the various UN actors have to work in a co-ordinated fashion, especially UNHCR and UNDP. ${ }^{109}$ Moreover, such inter-agency co-operation with a view to solutions must commence at the outset of the crisis, not just when the humanitarian phase is declared to be over. Solutions and protection are complementary, as will be explored further below, with the corollary that developmental actors need to be engaged from the outset. ${ }^{110}$ In this regard, Marshall ${ }^{111}$ is wrong to suggest that 'the early stages of UN field operations are not an appropriate context for comprehensive approaches'. He may be right that '[1]arge,

${ }^{107}$ See Press Release, 'Forced Displacement: A Developing World Crisis' (World Bank, 15 September 2016) <http://www.worldbank.org/en/news/press-release/2016/09/15/forceddisplacement-a-developing-world-crisis.print>. See also New York Declaration (n 5), and the affirmation of shared responsibility.

${ }^{108}$ See UN Development Action Framework (UNDAF) $<$ https://undg.org $>$ and UN Democracy Fund $<$ http://www.un.org/democracyfund/about-undef $>$.

${ }^{109}$ To an extent, this is the basis of the cluster approach for IDPs, see Inter-Agency Standing Committee on the Cluster approach $<$ https://interagencystandingcommittee.org/productcategories/cluster-approach>. The 2008 inventory by the Secretary-General of UN rule of law activities included 92 by UNHCR that prioritized protection and solutions for displaced persons.

${ }^{110}$ See Preamble to ExCom Conclusion 112 (n 5): 'Stressing the importance of the protection of human life and dignity as a priority issue by reaffirming, inter alia, the principle of non-refoulement, as well as the importance of providing assistance and seeking comprehensive approaches towards the implementation of durable solutions, as appropriate, from the outset of a displacement situation, while ensuring that no-one is left behind ...'.

${ }^{111}$ See (n 50120. 
comprehensive programmes have resulted in large, comprehensive failures', but this suggests that the UN has not viewed rule of law as a process, rather than as an end-state. UNHCR, UNICEF and UNDP, along with DPKO where appropriate, should participate in registration and documentation with the government, for example, so that all displaced persons can participate in the longer-term rule of law programmes. ${ }^{112}$

\section{(b) The humanitarian/development (false) dichotomy ${ }^{113}$}

If economic, social, and cultural rights are fully implemented within the rule of law, then the rights to work and shelter must be given prominence alongside freedom from arbitrary detention. ${ }^{114}$ Given that the modal average length of a protracted refugee situation is around 20 years, priorities will inevitably change and the humanitarian crisis that prompted flight will become a situation of protracted displacement. The displaced will then need to be seen as part of the development plans for the State of refuge as it continues to uphold the fundamental guarantee of non-refoulement. ${ }^{115}$

\footnotetext{
${ }^{112}$ See Goldston (n 63 22. See 'UNHCR Helps Displaced Iraqis Acquire Vital Documentation' <http://www.unhcr.org/news/latest/2017/7/596dcb2f4/unhcr-helpsdisplaced-iraqis-acquire-vital-documentation.html>.

${ }^{113}$ See New York Declaration (n 5) para 85, and Annex 1, para 2. See also ExCom Conclusion 112 (n 5) paras 9 and 12.
}

${ }^{114}$ See eg the plight of the 31,000 IDPs in Zamboanga city on Mindanao in the Philippines who lack access to secure housing, there was no early recovery strategy after the humanitarian phase and the development sector was slow to engage. See iDMC, 'Global Overview 2015: People Internally Displaced by Conflict and Violence' (May 2015) 60-61. ${ }^{115}$ Cartagena +30 , 'Brazil Declaration and Plan of Action: A Framework for Cooperation and Regional Solidarity to Strengthen the International Protection of Refugees, Displaced and Stateless Persons in Latin America and the Caribbean' (Brasilia, 3 December 2014) $<$ http://www.refworld.org/docid/5487065b4.html>. See Goldston (n 63 22, on how documentation gives access to education and health care eg for marginalized communities like refugees. See also Deputy Secretary-General Jan Eliasson, 'UN Deputy Chief Calls for Greater Integration Efforts to Meet Challenges of Refugees in Urban Areas' (18 May 2016) $<$ http://www.un.org/apps/news/story.asp?NewsID=53971\#.V8fenmXns7M>. In addition, see the UNHCR-OECD Memorandum of Understanding (15 June 2016) para 2, which sets 
13) ... the inadequate response to the needs of IDPs and refugees, particularly to developmental needs continues to be the single major obstacle to durable solutions for displaced persons. The continued perception that concerns of displacement can only be addressed by humanitarian means is ill-conceived and has resulted in the protracted displacements of millions of IDPs and refugees, unable to find solutions for their displacement that can assist them to break from the cycle of dependence on humanitarian assistance and to move on with their lives. ${ }^{116}$

Rule of law approaches that are underpinned by all human rights and whole society participation facilitate this understanding and promote stability and development in the State of refuge and the State of return. ${ }^{117}$ Equally, they promote interoperability between UNHCR and UNDP and the World Bank.

out substantive collaboration in relation to the protection and integration of refugees who are to be included in development programmes. See also, ILO Recommendation 205, 'Employment and Decent Work for Peace and Resilience Recommendation, 2017', and 'Jordan Compact 2016'<data.unhcr.org/syrianrefugees/download.php?id=12008>.

${ }^{116}$ Concept Note (n 9). Also, EU Press Release, 240/16 (12 May 2016), calls for '[a] coherent, development-led approach to forced displacement' (paras 5-8).

${ }^{117}$ Concept Note (n 9): ' 14 ) ... In both fragile and conflict affected countries, and in countries with robust institutional and governance frameworks, displacement can also become the setting for human rights violations and a breeding ground for serious grievances leading to conflict, general violence, crime and instability and further displacement'. See also Goldston (n 63 20; and GA res 67/1 (n 2) para 7: 'We are convinced that the rule of law and development are strongly interrelated and mutually reinforcing, that the advancement of the rule of law at the national and international levels is essential for sustained and inclusive economic growth, sustainable development, the eradication of poverty and hunger and the full realization of all human rights and fundamental freedoms, including the right to development, all of which in turn reinforce the rule of law, and for this reason we are convinced that this interrelationship should be considered in the post-2015 international development agenda'. The Global Compact on Refugees to be concluded in 2018 also adopts this approach, see UNHCR, 'Towards a Global Compact on Refugees: a Proposed Roadmap' (17 May 2017) para $10<$ http://www.unhcr.org/58e625aa7>. 
(c) Protection, solutions, and rule of law ${ }^{118}$

Very closely related to the humanitarian/development dichotomy is the question of protection and solutions. ${ }^{119}$ These two concepts are difficult to separate completely and both promote and are enhanced by rule of law approaches. Part of the problem has been to view solutions in the wake of displacement as relating only to durable and sustainable solutions: voluntary repatriation/return, resettlement/relocation, and local integration. This understanding tends to focus protection on documentation/registration and non-refoulement, the core, immediate rights (and needs) of the refugee. ${ }^{120}$ That renders all other human rights to which displaced persons are entitled in a rule of law State as secondary. This approach fails to recognise protection as part of solutions ${ }^{121}$ and that solutions, broadly conceived, are part of on-going protection, a process. ${ }^{122}$ First, registration/documentation allows a displaced

\footnotetext{
${ }^{118}$ Some of the examples that appear in this next section came to light during the field trips the authors undertook as part of their UNHCR consultancy in late 2014. The authors are grateful to UNHCR for permission to use this material.
}

${ }^{119}$ See 'The Centrality of Protection in Humanitarian Action' endorsed by the IASC Principals (17 December 2013)

$<$ https://interagencystandingcommittee.org/principals/content/centrality-protectionhumanitarian-action>. See also, the Brazil Declaration (n 115).

${ }^{120}$ See Guy S Goodwin-Gill and Jane McAdam, The Refugee in International Law (3rd edn, 2007) 335ff, esp 343-45.

${ }^{121}$ See how UNHCR's use of its Biometric Identity Management System for refugees from Myanmar/Burma in camps in Thailand provided registration data that helps UNHCR target assistance more accurately as the situation in Myanmar/Burma changes. The operation was carried out jointly with the Royal Thai Government with the support of civil society. See 'UNHCR's New Biometrics System Helps Verify 110,000 Myanmar Refugees in Thailand' (30 June 2015) <http://www.refworld.org/docid/5594f7594.html>. For information on how UNHCR protects the privacy rights of those on whom it holds such data, see UNHCR, 'Policy on the Protection of the Personal Data of Persons of Concern to UNHCR' (15 May $2015)<$ http://www.refworld.org/cgi-bin/texis/vtx/rwmain>.

${ }^{122}$ See Global Compact Proposed Roadmap (n 117 para 32(b). 
person to access their rights, thus facilitating, as will be seen, solutions. ${ }^{123}$ For example, the Internal Displacement Monitoring Centre has carried out a global study that shows that IDPs' inability to register their children at birth can result in statelessness and also a range of other human rights violations. ${ }^{124}$

The registration of children born to IDPs and the assistance and protection it unlocks also helps to prevent violations of their rights, including child labour, sexual exploitation, trafficking, early marriage and recruitment into the military and NSAGs. [A Norwegian Refugee Council] study on the living conditions of IDPs and host communities in the eastern DRC city of Goma showed that displaced children who were not registered and did not receive assistance were more likely to be recruited into child labour.

If registered, it is much easier for children to enter the education system. ${ }^{125}$ Moreover, improving access to education for children increases the likelihood that they will be in a position to take up opportunities for durable solutions. ${ }^{126}$ Equally, while a child is in school, it is much more difficult for them to be exploited and abused, enhancing protection. The same arguments, mutatis mutandis, apply to access to employment and training for displaced

\footnotetext{
${ }^{123}$ See New York Declaration (n 5) paras 71 and 75, and Annex 1, para 5(d), along with ExCom Conclusion 112 (n 5) para 2; and UNGA res 71/148 (n 2) para 20.

${ }^{124}$ See iDMC Discussion Paper, 'Getting on the List: The Registration of Children Born to IDPs' (15 May 2015) <http://www.internal-displacement.org/publications/2015/getting-onthe-list-the-registration-of-children-born-to-idps>. See also SDG 16.9 (n 53: 'By 2030, provide legal identity for all, including birth registration'; and New York Declaration (n 5) Annex 1, para 5(f).

${ }^{125}$ See 'Birth Certificates Issued by Mali Open Doors for Mauritanian Refugee Children' (UNHCR News, 20 April 2015) <http://www.unhcr.org/cgi$\mathrm{bin} /$ texis $/ \mathrm{vtx} / \mathrm{search}$ ?page $=$ search $\&$ docid $=5534 \mathrm{fc} 0 \mathrm{f} 1 \mathrm{~b} \&$ query $=$ Birth $\% 20$ certificates $\% 20$ issue d\%20by\%20Mali\%20open\%20doors\%20for\%20Mauritanian\%20refugee\%20children>. See also Global Partnership on Education <http://www.globalpartnership.org>; and the New York Declaration (n 5) paras 81 and 82.

${ }^{126}$ New York Declaration (n 5) Annex 1, para 13(b).
} 
persons, especially since much of the crime within camps arises from enforced idleness. ${ }^{127}$ Thus, while the ultimate goal is to find durable and sustainable solutions for displaced persons, giving them access to their rights during their displacement is part of the on-going solutions process. ${ }^{128}$ Access to rights is a requirement that a rule of law State upholding all its international obligations must meet vis à vis displaced persons on its territory and that concomitantly will promote their protection. A solution, therefore, like rule of law, should be seen as a process, the progressive resolution of the situation, not simply an outcome in some end-state. Additionally, it is a process that can be furthered through developmental approaches and thus should be shared with the State and other UN actors.

\subsubsection{Rule of law in practice}

Displaced persons' protection and access to solutions should be a part of any UN operation, regardless of whether a narrow or broad rule of law approach has been adopted. Policing, justice, and corrections promote security from violence and exploitation, ${ }^{129}$ and can also

\footnotetext{
${ }^{127}$ See Goodwin-Gill and McAdam (n 120 345, fn 416, quoting the Assistant High Commissioner's speech (Copenhagen, 23 October 2002) pointing out that camps are not a natural consequence of displacement, but are "established in response to political realities and constraints'.
}

${ }^{128}$ See 'Decision No. 2011/20 - Durable Solutions: Follow up to the Secretary-General's 2009 report on peacebuilding' (4 October 2011), following up on 'Ending Displacement in the Aftermath of Conflict: Preliminary Framework for Supporting a more coherent, predictable and effective response to the durable solutions needs of refugee returnees and internally displaced persons' <http://www.refworld.org/docid/5242d12b7.html>, particularly para (ii) of the Decision, and 1D, para 12 of the Preliminary Framework.

${ }^{129}$ See also Guidance Note of the Secretary-General, 'Reparations for Conflict-Related Sexual Violence 2014'

$<$ http://www.ohchr.org/Documents/Press/GuidanceNoteReparationsJune-2014.pdf>. Security from crime in camps can also be furthered through a rule of law approach that builds up the capacity of the State and displaced persons themselves with respect to policing; mobile courts that can visit camps further promote rule of law in situations of displacement, see UN Somalia Integrated Strategic Framework 2014-16, kindly supplied by UNDP and with the authors. 
enhance access to legal assistance and legal remedies, ${ }^{130}$ improve reception conditions, and further peaceful coexistence with local communities. The broader understanding of rule of law within the UN calls for laws that are 'consistent with international human rights norms and standards' from States that are 'accountable to laws that are publicly promulgated, [and] equally enforced', thus embracing all displaced persons. Furthermore, in terms of interoperability, a rule of law approach would allow UNHCR to widen its range of activities on behalf of displaced persons by drawing more fully on the expertise of other UN actors and by deploying its limited resources to protection issues. For instance, engaging with OHCHR, it could take on a more comprehensive role with respect to human rights treaty bodies and their ability to provide protection. ${ }^{131}$

As part of the UN Somalia Integrated Strategic Framework 2014-16, ${ }^{132}$ the UN adopted an approach to rule of law that included not only 'police, justice and corrections', but also 'security, gender equality, human rights, [and] advocacy for IDP protection'. A broad rule of law approach, with both formal and substantive components, permeates the entire Framework; cross-cutting issues are identified as: human rights, stabilization, gender, and capacity building of the government so that, in part, it can fulfil all its human rights obligations. Peacebuilding and Statebuilding Goal 3 incorporated access to justice for displaced persons in the rule of law based protection analysis. As part of any rule of law

\footnotetext{
${ }^{130}$ Compare Vivek Maru, 'Legal Empowerment and the Land Rush: Three Struggles' in Marshall (ed) (n 4) 205.

${ }^{131}$ See also Marshall (n 50 115-19. Additionally, working with the host State and OHCHR, the host State could launch a claim before the Human Rights Committee under art 41 against a completely intransigent source State as part of the former's obligations to all persons in its territory or jurisdiction. Such a move would be revolutionary and go beyond all current activities, but would fit a rule of law based approach and highlight on the world stage the situation of protracted displaced persons, even if any victory might be pyrrhic.

${ }^{132}$ Document kindly supplied by UNDP and with the authors. See also Somali National Development Plan 2017-19<http://www.mopic.gov.so/wpcontent/uploads/2016/06/National-Development-Plan-Summary.pdf $>$, which makes repeated references to the rule of law.
} 
engagement, the UN should be promoting human rights treaty ratification, which coincides with UNHCR's mandate. ${ }^{133}$

In terms of the broad approach to rule of law issues and outcomes within a State, one of the major problems in situations of displacement is that land is a fixed and often limited commodity that is never terra nullius. ${ }^{134}$ Therefore, providing land to displaced persons is not simple. It requires discussion with the government at national and local levels to introduce legislation that reflects principles of equality, fairness, certainty, and transparency, where this is lacking, and that complies with international standards. Consulting with the national population and with displaced persons during the drafting phase will help to ensure rule of law compliant legislation that takes full account of the displacement-specific needs of refugees and IDPs, particularly in a context of very limited resources. Clearly, these changes should be part of the national planning exercises of the government, undertaken with other UN actors, such as UNDP and UN Habitat. ${ }^{135}$

In some cases, the land issues are very complex. The displaced persons may need something other than a transfer of individual title; for instance, they may have a collective approach to land ownership, or their livelihoods may depend on general access to vast swathes of territory already used by the national population. In these cases, the

\footnotetext{
${ }^{133}$ See 1950 Statute (n 6) para 8a. Specifically, with UNDP, UNHCR is engaging in police training on, amongst other matters, GBV.

${ }^{134}$ See Norwegian Refugee Council/International Federation of the Red Cross, 'The Importance of Addressing Housing, Land and Property (HLP): Challenges in Humanitarian Response' (2016) <http://www.ifrc.org/Global/Documents/Secretariat/Shelter/IFRCNRC\%20HLP\%20report\%202016.pdf>. See also SU-039/97 (3 February 1997), T-821/07 (October 2007), and T-267/11 (April 2011), Colombian Constitutional Court, cited in OHCHR, 'Land and Human Rights: Annotated Compilation of Case Law' 75-77 (2015), on how land issues interrelate to other aspects of rights, rule of law, and the protection of displaced persons.

${ }^{135}$ See Colombian Law No 1448 on Victims and Land Restitution of 2011, as well as, Constitutional Court, decision T-312/10

$<$ http://www.corteconstitucional.gov.co/relatoria/2010/T-312-10.htm $>$ (thanks are due to Camilo Sánchez of Dejusticia for this material). See also New York Declaration (n 5) Annex 1 , para 11.
} 
developmental aspects of rule of law can benefit solutions: for instance, a complex, multifaceted land registration project within the UN Development Assistance Framework, as a product of work with UNDP, advocating alongside UN Habitat, as well as capacity building with the government at national level, would help to ensure durable and sustainable solutions for displaced persons. ${ }^{136}$ In sum, land is a multifaceted issue because it is pertinent from the moment of arrival through to any eventual durable and sustainable solution. Moreover, housing, land, and property, and other areas of intervention, are characterized by interdependence: housing, land, and property depend on proper documentation and registration, while physical security and protection from SGBV benefits from secure and stable housing. ${ }^{137}$ Often, housing, land, and property cannot be considered separately from other measures that aim to provide protection and solutions to displaced persons.

3.4 Rule of law as the only effective response for international organizations

The problematique of displacement reveals how a rule of law approach provides a comprehensive and effective response to a challenging global problem. Rule of law facilitates seeing the different areas of UNHCR's engagement with displaced persons and governments (in source and refuge States) as interlinked, which only in combination realize the full panoply of rights to which displaced persons are entitled. UNHCR clearly benefits from a rule of law based approach because: (i) the international human rights standards, on which it would ordinarily rely in discussions with the State, are not always fully developed with respect to displaced persons to achieve the desired ends; (ii) a functioning government that can uphold, after capacity building, its own fair and equitable laws is essential if displaced persons are to return or integrate locally; and (iii) other UN actors whose primary

\footnotetext{
${ }^{136}$ For example, Niger ranks 187 th out of 188 States in UNDP's Humanitarian Development Report for $2016<\mathrm{http}: / /$ hdr.undp.org/en>, and its UNDAF should reflect that the government, with the local chefs $d u$ village, have provided grazing rights to refugee Malian nomads and building plots to Nigerians fleeing Boko Haram; see World bank's IDA Fund $<$ http://ida.worldbank.org/results/country/niger>. Also see iDMC, 'Urban Informal Settlers' (June 2015) and 'Home Sweet Home' (May 2015) <http://www.internal-displacement.org>. ${ }^{137}$ UNDP-UNHCR Transitional Solutions Initiative (TSI) Joint Programme, Durable Solutions through enhanced self-reliance for refugees, internally displaced persons and host communities in Eastern Sudan, $<$ http://www.sd.undp.org/content/dam/sudan/docs/project_docs/cp16\%20UNDPUNHCR\%20JP\%20ProDoc\%2012\%20Feb.pdf> para 27.
} 
focus is developmental can assist in ensuring that solutions are durable and sustainable as part of a wider national plan. ${ }^{138}$

UNHCR has a unique mandate for refugees, returnees, asylum seekers, and IDPs, but this does not mean it needs to shoulder the entire burden itself if it needs to establish a parallel State for displaced persons. The substantive/thick rule of law, in the broad form adopted by the UN, encompasses the current rights and needs focus, but starts with the premise that the State will provide protection and facilitate durable and sustainable solutions, possibly in conjunction with the more development-focused UN agencies. Certainly, UNHCR may have to engage in capacity building and monitor State activities, in line with its article 35 supervisory function, to enable the State to provide protection, but that is preferable to having to act as a substitute for the State. ${ }^{139}$ A State with a properly functioning legal system that ensures equality before the law will allow displaced persons to claim their rights and obtain protection. In addition, the rule of law approach better accommodates the reality of displacement. Very few situations, either cross-border or internal, are short-term, where the displaced persons can soon return home. In many cases, displacement is protracted and the immediate protection paradigm of shelter, food, and distribution of non-food items could soon become a culture of dependency. A rule of law approach that engages with the State and with other UN actors has a greater chance of facilitating UNHCR's operation in that State and of including displaced persons in national planning strategies that will enhance the likelihood of self-reliance and durable and sustainable solutions through education and livelihood programmes.

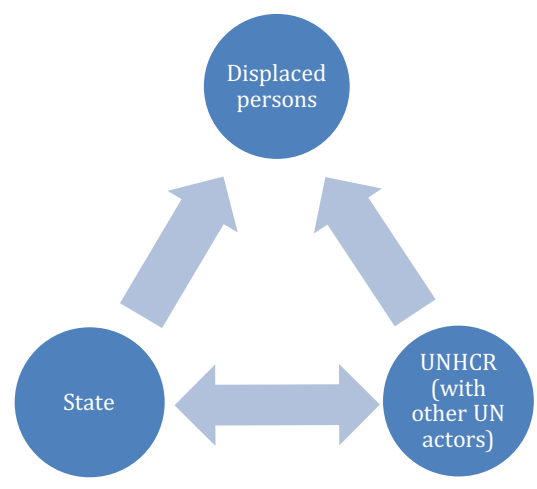

${ }^{138}$ See, Concept Note (n 9); and <http://www.unhcr.org/pages/49e492ad6.html>; East Sudan TSI (n 137; Colombia (n 10); and Somalia Initiative (n 132.

${ }^{139}$ See Türk and Garlick (n 5) 659ff. 
Furthermore, a rule of law approach by the UN may further two implicit goals: reliance on international human rights norms and standards, where the State is not party to a particular treaty; and not having to use human rights language in a State that treats international human rights law as a tool of the global north. Because rule of law was reaffirmed by the General Assembly in the 2012 Declaration, ${ }^{140}$ it is easier to argue that States ought to implement measures that can be said to derive from the Secretary-General's 2004 report. $^{141}$ At one level, rule of law was introduced after the concepts of human rights and international protection did not achieve the results for which people had hoped. It attaches obligations to States by appealing to something to which they had already committed, without needing ratification, a decision of some international court, or the intervention of the Security Council. ${ }^{142}$ If that is the aim, however, in the context of rule of law it may be misplaced. International law is created in various ways to which States have consented. If States have adopted a procedure for the creation of laws that does not oblige them to assume international human rights norms and standards, ${ }^{143}$ does reading those obligations back in, via the UN's understanding of rule of law, risk procedural irregularity that undermines the very essence of rule of law as accepted by the theorists? If this is an implicit consequence of the broad approach to a substantive/thick rule of law adopted by the $\mathrm{UN}$, then it raises questions concerning 'procedural and legal transparency'. To be sure, thick rule of law requires a human-centric approach that promotes the protection of the individual, but it equally respects the law pertaining to treaties and customary international law. It also provides the basis for asking how rule of law applies within the UN.

\section{RULE OF LAW/RECHTSSTAATFOR THE UN AND THE INTERNATIONAL RESPONSIBILITY OF INTERNATIONAL ORGANIZATIONS}

\footnotetext{
${ }^{140}$ See UNGA res 67/1 (n 2).

${ }^{141}$ See 'Legality of the Threat or Use of Nuclear Weapons, Advisory Opinion' ICJ Rep 226 (8 July 1996) para 70.

${ }^{142}$ McCorquodale (n 1) 294. Also see Alvarez (n 12) 33-34.

${ }^{143}$ See Besson (n 84 383-84. The 'thick' approach to rule of law (Bingham (n 18)) runs the risk of seeming to sneak human rights in via the back door. See also Chesterman (n 18) 360 .
} 
The 2012 General Assembly Declaration states that the rule of law applies just as much to the UN. ${ }^{144}$ How, if at all, does a rule of law approach fit with the responsibility of international organizations in international law? ${ }^{145}$ The responsibility of international organizations in general raises a plethora of issues that are beyond the remit of this article, ${ }^{146}$ but applying rule of law principles in situations of displacement involves international organizations in interactions with States - some that are members of those organizations, some possibly not; with other international organizations; with NGOs; and with individuals. ${ }^{147}$ To the extent that the UN interacts directly with individuals, then quite clearly the 2012 Declaration assumes that it will uphold the rule of law. However, not being a sovereign State with all the attributes, functions, and powers that a State would possess, there may need to be some modifications as to its implementation. And if rule of law applies just as much to the UN, then what are the internal consequences? This last mentioned aspect is rarely addressed, if at all, in discussions on rule of law in an international context. ${ }^{148}$

It is not enough to refer to the 2012 Declaration and simply assert that as a consequence rule of law applies to the UN. A General Assembly Declaration does not

\footnotetext{
${ }^{144}$ See UNGA res 67/1 (n 2).

${ }^{145}$ See ILC, 'Draft articles on the responsibility of international organizations' UN doc
} A/66/10 (2011) (DARIO). The status of the Draft Articles is unclear, but they are used here to illustrate the problems of holding an international organization accountable with respect to rule of law objectives, see also Michael Wood, “'Weighing” the Articles on Responsibility of International Organizations' in Maurizio Ragazzi (ed), Responsibility of International Organizations (2013).

${ }^{146}$ See generally Jan Klabbers, An Introduction to International Institutional Law (2nd edn, 2011); the very full discussion in Klabbers (n 92; and Kristina Daugirdas, 'Reputation and the Responsibility of International Organizations' (2014) 25 European Journal of International Law 991. Also see Alvarez (n 12); and McCorquodale (n 1).

${ }^{147}$ Where UNHCR has the statutory mandate. Of course, the State remains potentially liable as well, see DARIO (n 145 art 19. See also Affaire D et autres c Turquie App no 24245/03 (ECtHR, Third Section, 22 June 2006).

${ }^{148}$ There is a tendency to treat the UN as one monolithic organization, even if there are hints of some dysfunctionality - see Marshall (ed) (n 4). Compare Kanetake and Nollkaemper (eds) (n 17); Alston (n 74; and, Sarfaty, Klabbers, and Santos, all (n 92. 
establish international law in and of itself, although it may reflect customary international law that might be binding on the UN as much as States. And that would still leave open questions about the scope of those obligations, how they might be implemented and issues of accountability and immunity. If, however, the UN were to be unaccountable for its own actions, then a principal actor in humanitarian crises would be outside the rule of law. ${ }^{149}$ As Hovell has commented, due process grants legitimacy: 'Safeguards associated with due process aim collectively to open up a structured dialogue between decision-making authority and those affected by decisions. Broadly, the aim of this dialogue is to enhance legitimacy'. ${ }^{150}$ Hovell's understanding of due process would embrace similar values to

149 See Ratner (n 84 262. See also, Palombella (n 14) 10; Harlow (n 14) 191; Alvarez (n 12) 24-25, along with James Crawford, cited by Alvarez at fn 29, 10; Christian Tomuschat, 'The Security Council and Jus Cogens' in Enzo Cannizzaro (ed), The Present and Future of Jus Cogens (2015) 7, paras 70 and 71: 'It is a derivative institution like the world organization as a whole while States have their own legitimacy by virtue of the pouvoir constituant of their peoples. The UN, by contrast, is still a child of the States having established it by virtue of an international treaty. Accordingly, the member States are still the masters of the world organization, being able additionally to leave it if they so wish .... Whoever was born from the law and within the law, must respect the law. It cannot argue that it has a higher raison d'être permitting it to disregard its foundation in accordance with political convenience'. Rosalyn Higgins, 'The Place of International Law in the Settlement of Disputes by the Security Council' (1970) 64 American Journal of International Law 1; and Nabil Sayadi and Patricia Vinck v Belgium, CCPR/C/94/D/1472/2006 (29 December 2008) Individual opinion (partly dissenting) by Committee members, Sir Nigel Rodley, Mr Ivan Shearer, and Ms Iulia Antoanella Motoc, 27: 'We acknowledge, of course, that the authors may have been unjustly harmed by operation of the extravagant powers the Security Council has arrogated to itself, including the obstacles it has created to the correction of error. It is more than a little disturbing that the executive branches of 15 Member States appear to claim a power, with none of the consultation or checks and balances that would be applicable at the national level, to simply discard centuries of States' constitutional traditions of providing bulwarks against exorbitant and oppressive executive action'.

${ }^{150}$ See Hovell (n 17) 4. Also see Thomas Franck, Fairness in International Law and Institutions (1995). 
substantive/thick rule of law, as explained in this article. ${ }^{151}$ Modern, post-1945 Rechtsstaat, incorporating common law rule of law values that restrain the sovereign, embraces the constitutional structures that should shape how the UN acts in its operations and the coherent framework for the organization in terms of operationalizing interoperability. Thus, while responsibility may entail accountability in some form for the UN, if it adopts rule of law, it aids its legitimacy as an actor in humanitarian crises. ${ }^{152}$

According to the ILC DARIO, '[e]very internationally wrongful act of an international organization entails the international responsibility of that organization'; ${ }^{153}$ the Declaration of the High-level Meeting of the General Assembly on the Rule of Law at the National and International Levels of 2012 proclaims that all institutions are 'accountable to ... laws'. ${ }^{154}$ Thus, to the extent that an international organization is responsible for an internationally wrongful act, it should be accountable. ${ }^{155}$ Article 4 of the DARIO provides as follows:

Article 4

Elements of an internationally wrongful act of an international organization

${ }^{151}$ See Hovell (n 17) 3. Hovell bases many of her arguments relating to due process on cases that other authors use with respect to rule of law - see Kanetake and Nollkaemper (eds) (n 17) - but see Hovell, at 17.

${ }^{152}$ On the nuanced relationship between responsibility and accountability, see Tony Honoré, Responsibility and Fault (2002) 3, 10-11, 130-33: 'Accepting responsibility for our actions makes for a better society because it encourages us to do well and to enjoy the credit that comes from doing well. Above all, the system of responsibility is essential to our self-respect and our respect for others' 10. See also Rosalyn Higgins, Problems and Process:

International Law and How We Use It (1994) 147-48; Alvarez (n 12) 24-25; Loughlin (n 3) 340-41. The authors are indebted to colleagues, the late Sir Nigel Rodley and Paul Hunt, for the discussions on this topic and the additional complications that arise when trying to apply it to international organizations.

${ }^{153}$ See DARIO (n 145 art 3.

${ }^{154}$ See UNGA res 67/1 (n 2) para 2.

${ }^{155}$ See Honoré (n 152 3-4. 
There is an internationally wrongful act of an international organization when conduct consisting of an action or omission:

(a) is attributable to that organization under international law; and

(b) constitutes a breach of an international obligation of that organization.

The question is, therefore, whether the failure to uphold rule of law principles in relation to the State, an individual, or other international organizations 'constitutes a breach of an international obligation of that organization'. According to article 33.1, the DARIO of 2011 are geared towards responsibility to States and as between international organizations themselves, ${ }^{156}$ although article 33.2 asserts that it is without prejudice to the responsibility of an international organization that might 'accrue directly to any person or entity other than a State or an international organization'. It is unlikely that failure by one part of the UN to cooperate with another would amount to an internationally wrongful act, so the DARIO have little directly to add to interoperability. An exception might be a World Bank programme that failed properly to respect non-refoulement, but it is unlikely in such circumstances that the DARIO would provide the appropriate framework for UNHCR's response. As for responsibility that might accrue directly in international law to individuals who are displaced, that might facilitate rule of law and may indirectly promote interoperability.

4.1 International organizations and the source of accountability to individuals ${ }^{157}$ How might an international organization be accountable to individuals for its actions? ${ }^{158}$ If such accountability could be operationalized, might there be cases where it promotes

\footnotetext{
${ }^{156}$ See Mateja S Platiše, 'The Development of the Immunities of International Organizations in response to Domestic Contestations' in Kanetake and Nollkaemper (eds) (n 17) 84. As for the UN's responsibility to Member States, the UN and its organs are accountable through the General Assembly under the various reporting mechanisms and through any Memorandum of Understanding with that State. The situation might sometimes be more complicated because the UN is made up of and acts on behalf of those self-same States, see Klabbers (n 92 25ff and 54-55; and James Crawford, Brownlie's Principles of International Law (8th edn, 2012) 580ff.

${ }^{157}$ Alvarez (n 12) 15.

${ }^{158}$ An individual has no right of audience before the ICJ, States cannot seek a review of the decision of any UN organ before the ICJ, only organs of the UN can seek an Advisory
} 
interoperability? The starting point must be to determine which obligations of an international organization give rise to duties towards individuals. If such obligations arise, then the ways in which accountability might be effected and implemented will need to be explored. Failure to provide an effective accountability mechanism undermines the rule of law.

The obligations of an international organization are found in its constituent documents and in the international instruments under which it is bound. For the UN, that would primarily be its Charter. The purposes of the UN, set out in article 1, include achieving 'international cooperation in solving international problems of an economic, social, cultural, or humanitarian character, and in promoting and encouraging respect for human rights and for fundamental freedoms for all without distinction as to race, sex, language, or religion'. While the UN does not ratify the international human rights law treaties that it promulgates, the Universal Declaration of Human Rights has been said to establish a set of norms for the organization. ${ }^{159}$

In the crucible of mass displacement, how should this be understood? UNHCR's mandate is declared in its Statute, but it has expanded considerably so that a much broader

Opinion of the ICJ to query the validity of a decision. See generally White (n 73 206-16, for a detailed discussion of these matters.

${ }^{159}$ As to the institutionally binding quality of the UDHR within the UN, see Eibe H Riedel, 'Article 55(c)' in Bruno Simma (ed), The Charter of the United Nations (2nd edn, 2002) vol II, 917-27, where it is argued that there is wide acceptance that art 55(c) of the UN Charter is binding on the organization (920 and 922-23) and that the UDHR represents the first step by UN organs to realize 'the programme enshrined in Article 55(c)' (925). See also Guglielmo Verdirame, The UN and Human Rights: Who Guards the Guardians? (2011); Geoff Gilbert, 'Implementing Protection: what refugee law can learn from IDP law ... and vice versa' in Geoff Gilbert, Françoise Hampson, and Clara Sandoval (eds), The Delivery of Human Rights (2011); Niamh Kinchin, 'The Implied Human Rights Obligations of UNHCR' (2016) 28 International Journal of Refugee Law 251; and Frédéric Mégret and Florian Hoffmann, 'The UN as a Human Rights Violator? Some Reflections on the United Nations Changing Human Rights Responsibilities’ (2003) 25 Human Rights Quarterly 314. 
range of persons are now of concern to the High Commissioner. ${ }^{160}$ Moreover, as well as the international human rights law obligations arising from the Charter, UNHCR's Statute sets out, in paragraph 1, that it 'shall assume the function of providing international protection ... to refugees', thus providing another avenue for attributing responsibilities towards those displaced. UNHCR's Statute defines protection, in paragraph 8, in broad terms that incorporate promoting the conclusion and ratification of international conventions, promoting through special agreements with governments measures calculated to improve the situation of refugees, as well as facilitating the co-ordination of the efforts of private organizations concerned with the welfare of refugees. ${ }^{161}$ Furthermore, the cluster approach, ${ }^{162}$ where UNHCR has the lead for international protection and the co-lead on shelter and camp co-ordination and camp management for conflict-IDPs, brings together various UN actors, once again for protection and humanitarian assistance and, in this case, interoperability is explicit. If all those UN actors who engage directly with individuals affected by displacement follow the 2012 General Assembly Declaration, they must promote the rule of law, a common approach that should equally promote interoperability. ${ }^{163}$

${ }^{160}$ UNHCR Statute (n 6); and Türk and Eyster (n 7). See also Guy S Goodwin-Gill, 'The Movements of People between States in the 21st Century: An Agenda for Urgent Institutional Change' (2016) 28 International Journal of Refugee Law 679.

${ }^{161}$ Para 10 goes on to provide that the 'High Commissioner shall administer any funds, public or private, which he receives for assistance to refugees, and shall distribute them among the private and, as appropriate, public agencies which he deems best qualified to administer such assistance' (emphasis added).

${ }^{162}$ See Inter-Agency Standing Committee (n 109.

${ }^{163}$ The experience of the authors in Colombia, during the consultancy for UNHCR, was that the UN's Resident Co-ordinator was fundamental to the concerted approach to IDPs by UNHCR, OHCHR and UNDP alongside the government, all of whom had adopted a rule of law approach. See also the TSI (n 9) and (n 10). For an example of an international organization promoting rule of law with respect to the privacy of individuals with whom it acts, see UNHCR's policy on data protection for persons of concern to the High Commissioner, UNHCR, UNHCR's New Biometrics System (n 121). 
Beyond constituent instruments, international organizations can be bound by general international law. ${ }^{164}$ Peremptory norms that protect individuals should clearly be binding. ${ }^{165}$ In this particular context, Responsibility to Protect ${ }^{166}$ (R2P) could establish a set of obligations for international organizations. In this regard, it must be noted that R2P is more than simply a justification to intervene in a State through the use of force sanctioned under chapter VII. In his follow-up to the World Summit Document 2005, the Secretary-General established a three pillar strategy for R2P. ${ }^{167}$ Pillar 2 deals with international assistance and capacity building: as paragraph 43 makes clear, 'chronic underdevelopment ... can exacerbate the competition for scarce resources and severely limit the capacity of the State, civil society, and regional and sub-regional organizations to resolve domestic tensions peacefully and fully'. ${ }^{168}$ The Secretary-General went on to emphasize the importance of rule of law capacity building in this context:

\footnotetext{
${ }^{164}$ Interpretation of the Agreement of 25 March 1951 between the WHO and Egypt, Advisory Opinion, ICJ Rep 73 (20 December 1980) para 48.
}

${ }^{165}$ See Jurisdictional Immunities of the State (Germany v Italy: Greece Intervening) ICJ Rep 99 (3 February 2012); Dissenting Opinion of Judge Cançado Trindade, and the suspension of South Africa by the World Meteorological Organization as a consequence of apartheid, referred to in Klabbers (n 92. Also see DARIO (n 145 art 26; and the International Law Association, 'Final Report of the Committee on the Accountability of International Organisations' (Berlin 2004) 26ff.

${ }^{166}$ See World Summit Outcome 2005 (n 64 paras 138-40: '139 ... In this context, we are prepared to take collective action, in a timely and decisive manner, through the Security Council, in accordance with the Charter, including Chapter VII, on a case-by-case basis and in cooperation with relevant regional organizations as appropriate, should peaceful means be inadequate and national authorities are manifestly failing to protect their populations from genocide, war crimes, ethnic cleansing and crimes against humanity'. See also paras 11 and 134.

${ }^{167}$ Report of the Secretary-General, 'Implementing the responsibility to protect' UN doc A/63/677 (12 January 2009) paras 28-48. The authors are grateful to Sabrina Rau, LLM 2015-16, for the discussions on this topic as part of her masters dissertation.

${ }^{168}$ See (n 64 para 44: 'What is most needed, from the perspective of the responsibility to protect, are assistance programmes that are carefully targeted to build specific capacities 
47. The rule of law is fundamental to preventing the perpetration of crimes relating to the responsibility to protect. The United Nations system, including through the engagement of donor countries, should increase the rule of law assistance it offers to Member States.

The Secretary-General expressly acknowledged the role of UNHCR in these programmes but, equally clearly, no single UN body could fulfil the requirements of R2P, thus obligations owed to individuals demand UN interoperability. ${ }^{169} \mathrm{R} 2 \mathrm{P}$ is but one example of a set of international obligations that are binding on States and on international organizations working in these contexts, but it is an extreme example - UNHCR's mandate to provide international protection to refugees is clearly of a different order. However, rule of law protects human rights and demands of States and international organizations that remedies are available to victims of violations.

On the other hand, though, on many occasions where the UN fails to perform to the highest possible standards, it is due to the failure by States, its members, to provide funds, especially voluntary contributions, and other resources. This raises questions about the responsibility of the UN for any internationally wrongful act arising from this shortfall, and about whether the Member States are fulfilling their rule of law responsibilities by leaving

within societies that would make them less likely to travel the path to crimes relating to the responsibility to protect'.

${ }^{169}$ See (n 64 para 30: ' ... Among those well placed to contribute to such good offices and public diplomacy efforts are regional and subregional mechanisms, the United Nations High Commissioner for Human Rights, the United Nations High Commissioner for Refugees, the Emergency Relief Coordinator, the Special Adviser on the Prevention of Genocide, other special advisers, special representatives and envoys of the Secretary-General, and ranking officials of the United Nations, its development agencies and the Bretton Woods institutions. When these messages are reinforced by parallel and consistent Member State diplomacy, they will be more persuasive. Dialogue often achieves more than grandstanding, in part because it can provide parties with greater insight into each other's motivations and intentions'. 
the UN ill-equipped. ${ }^{170}$ As Klabbers makes clear, ${ }^{171}$ the relationship of complex international organizations, such as the UN, with its Member States does not lend itself readily to the attribution of responsibility.

4.2 International organizations and the operationalization of accountability

If the preceding subsection establishes the responsibility of the UN under rule of law criteria to individuals, can the UN be held accountable? There is a good deal of discussion regarding rule of law that focuses on how courts balance power between elites and citizens, ${ }^{172}$ but there is little on how the UN and individuals within its protection achieve such a balance. The UN has immunity from action in the domestic courts of the States where it operates, in much the same way as another State would have. ${ }^{173}$ The lack of a viable mechanism for establishing the accountability of the UN undermines rule of law, ${ }^{174}$ although the criticism may not always be wholly deserved. The UN operates through its Member States and the resources put at its disposal - sometimes those resources, such as troops for a peacekeeping operation,

\footnotetext{
${ }^{170}$ Note: on the applicability of the principle of legality to economic questions, see Fuller (n 28 170ff, esp 172-73. Therefore, if the rights of individuals are to be protected, including economic, social and cultural rights, the UN has to adopt a substantive/thick approach to rule of law because the principle of legality is inadequate in this regard.

${ }^{171}$ See (n 92. See also White (n $73219 f f$.

${ }^{172}$ See eg Dworkin, A Matter of Principle 26-28, and Law's Empire 208ff, both (n 29; Goldston (n 63 18-19; Harold H Koh, 'Why Do Nations Obey International Law?' (1997) 106 Yale Law Journal 2599, 2622; Report of the Special Rapporteur to the Human Rights Council A/HRC/27/56 (27 August 2014) para 64; and David Tolbert and Andrew Solomon, 'United Nations Reform and Supporting the Rule of Law in Post-Conflict Societies' (2006) 19 Harvard Human Rights Journal 29, 46.

${ }^{173}$ See UN Charter, art 105; the Convention on the Privileges and Immunities of the United Nations, 1 UNTS 15 (1946); as well as all the bilateral treaties with States where the UN has offices. See also Klabbers (n 92 27, and (n 146 149; Michael Wood, 'Do International Organizations Enjoy Immunity Under Customary International Law' in Niels Blokker and Nico Schrijver (eds), Immunity of International Organizations (2015) 59-60; Crawford (n 156 74-78; and Geoff Gilbert, 'Rights, Legitimate Expectations, Needs and Responsibilities: UNHCR and the New World Order' (1998) 10 International Journal of Refugee Law 349. ${ }^{174}$ See Goldston (n 63 18; Klabbers (n 92 72; and Alvarez (n 12) 37-42.
} 
also answer to their capital. ${ }^{175}$ That said, this does not rule out joint accountability between the UN and the State, such that the lack of an accountability mechanism that could apportion responsibility is still a major cause of concern with respect to the rule of law's legitimacy as regards the $\mathrm{UN} .{ }^{176}$ The common law understanding of rule of law as a restraint on the governing body, ${ }^{177}$ combined with the post-1945 Rechtsstaat as a prevailing, internalized principle for the organization, should best describe its implementation by the UN.

Building on a line of case law from domestic and international courts, however, it is suggested that failure by the UN to provide a means by which to remedy a breach could limit the scope of its immunity. There is developing jurisprudence that the immunity of international organizations depends on the organization establishing an internal mechanism to respond to breaches of its obligations. ${ }^{178}$ In Internationale Handelsgesellschaft mbH $v$ Einfuhr- und Vorratsstelle für Getreide und Futtermittel (Solange 1), ${ }^{179}$ the Bundesverfassungsgericht ( $B V \operatorname{erf} G)$ held that the failure by the European Communities (EC) to provide a means by which to protect the human rights of German citizens, as set out in its constitution, meant that the German courts would continue to protect those rights vis à vis the EC. Solange 1 was based on the principle of proportionality, fundamental to substantive/thick rule of law. It was only as the EC established a human rights-based approach that the $B V \operatorname{erf} G$ acknowledged the primacy of EC legislation. In Waite and

${ }^{175}$ See the discussions in Behrami and Behrami v France App no 71412/01, and Saramati $v$ France, Germany and Norway App no 78166/01 (ECtHR, Grand Chamber, 2 May 2007); $R$ (Al-Jedda) v Secretary of State for Defence [2007] UKHL 58; and Al-Jedda v UK App no 27021/08 (ECtHR, Grand Chamber, 7 July 2011) esp paras 74-86.

${ }^{176}$ See DARIO (n 145 arts 61 and 45. And see Hovell (n 17) 45-46.

${ }^{177}$ Palombella (n 14) 16.

${ }^{178}$ See UN 1946 Convention (n 173 art VIII, Settlement of Disputes, s 29: 'The United Nations shall make provisions for appropriate modes of settlement of: (a) disputes arising out of contracts or other disputes of a private law character to which the United Nations is a party; (b) disputes involving any official of the United Nations who by reason of his official position enjoys immunity, if immunity has not been waived by the Secretary-General'. See also art II, s 2; art V, ss 18, 20 and 21.

${ }^{179}$ See [1974] 2 CMLR 540 (fortunately, aka Solange 1). See also Urban v United Nations 768 F.2d 1497, 1500 (DC Cir, 1965). 
Kennedy $v$ Germany ${ }^{180}$ the European Court of Human Rights held that 'a material factor in determining whether granting [the European Space Agency] immunity from German jurisdiction is permissible under the Convention is whether the applicants had available to them reasonable alternative means to protect effectively their rights under the Convention'. The right of access to a court or other adjudication mechanism for a remedy, however, is not absolute and respecting the immunity of an international organization may limit an individual's rights if it is proportionate. ${ }^{181}$ However, if the failure to provide a remedy relates to fundamental rights or a more egregious breach, then there will need to be greater justification for denying a route to a remedy.

The series of cases brought by the Mothers of Srebrenica in the Dutch courts against the UN and the Dutch government, as a consequence of Dutch troops in the enclave not providing the protection expected of them, is instructive in this regard. Six thousand Bosnians, including the Mothers of Srebrenica, began a case against The Netherlands and the UN for failing to prevent the deaths of thousands at Srebrenica. The UN claimed immunity and refused to take part in the case, and the Dutch government supported them on the ground that if immunity was lost it would constrain how the UN operates in peacekeeping situations. The Dutch District Court in The Hague found the UN had immunity under its Charter, but held the applicants could sue The Netherlands. ${ }^{182}$

${ }^{180}$ App no 26083/94 (ECtHR, Grand Chamber, 18 February 1999) para 68. See also Bosphorus Hava Yollari Turizm Ve Ticaret Anonim Şirketi v Ireland App no 45036/98 (ECtHR, Grand Chamber, 30 June 2005) paras 155-57.

${ }^{181}$ See Al-Dulimi (n 65 paras 128-31. See also the Concurring Opinion of Judge Pinto De Albuquerque, Joined by Judges Hajiyev, Pejchal and Dedov, paras 33-34 and 40.

${ }^{182}$ See 'Srebrenica victims cannot sue UN' (BBC News, 10 July 2008) $<$ http://news.bbc.co.uk/1/hi/world/europe/7500456.stm> accessed 30 April 2017. This was upheld by the Dutch Supreme Court in Mothers of Srebrenica Association v The State of The Netherlands and the United Nations 10/04437 (13 April 2012) para 4.3.14 $<$ https://www.rechtspraak.nl/Organisatie/Hoge-Raad/Supreme-court/Summaries-of-someimportant-rulings-of-the-Supreme-Court/Pages/Ruling-Dutch-Supreme-Court-Mothers-ofSrebrenica.aspx $>$. The Hague District Court went on to find the Dutch government liable for the deaths of 300 at Srebrenica, but not of another 7,000, which was then upheld on appeal to the Court of Appeals at The Hague (Gerechtshof Den Haag) 
Nevertheless, if rule of law applies to the UN in its operations as much as it does to States, then mechanisms need to exist to assess its compliance. ${ }^{183}$ One might argue that the $\mathrm{UN}$, by analogy with the law relating to rescuers, ought to receive a wider discretion, but it cannot be absolute. ${ }^{184}$ In one important respect for this article, such a mechanism is already in place: where UNHCR carries out refugee status determination on behalf of a State, then the applicant can appeal a refusal. A more wide-ranging example can be seen with respect to the UN Mission in Kosovo (UNMIK), where the UN was effectively governing a territory. Paragraph 11(j) of Security Council Resolution 1244 of 10 June 1999 had established that UNMIK would protect and promote human rights. UNMIK Regulation No 1999/1 185 provided, in section 2 , that ' $[i] \mathrm{n}$ exercising their functions, all persons undertaking public duties or holding public office in Kosovo shall observe internationally recognized human rights standards and shall not discriminate against any person'. Regulation No 1999/24 ${ }^{186}$ provided, in section 1.3, that UNMIK authorities should observe international human rights law, including the International Covenant on Civil and Political Rights. ${ }^{187}$ In addition, the Council of Europe and UNMIK negotiated that the latter would comply with the Framework Convention for Protection of National Minorities. ${ }^{188}$ In relation to the commitments under the ICCPR and the FCNM, UNMIK filed periodic reports to the relevant treaty body as to its

ECLI:NL:GHDHA:2017:1761 (27 June 2017). The 300 had been handed over by Dutchbat from the UN base at Potocari, but the 7,000 had not been handed over - the Dutch had just failed to protect them giving rise to no liability. NB. The Netherlands' loss of immunity for a UN operation might make States wary of sending troops to peacekeeping operations. 'Dutch state liable over 300 Srebrenica deaths' (BBC News, 16 July 2014)

$<$ http://www.bbc.co.uk/news/world-europe-28313285> accessed 30 April 2017. See also Klabbers (n 92 65-66.

${ }^{183}$ See Hovell (n 17) 34, 35.

${ }^{184}$ See Honoré (n 1529.

${ }^{185}$ UNMIK/REG/1999/1, 25 July 1999.

${ }^{186}$ UNMIK/REG/1999/24, 12 December 1999.

${ }^{187}$ GA res 2200A (XXI), 21 UNGAOR Supp (No 16) at 52 (1966), 999 UNTS 171.

${ }^{188}$ See 890th meeting of the Committee of Ministers (30 June 2004) app 2 $<$ https://wcd.coe.int/ViewDoc.jsp?id=757961\&Site=CM $>$. The FCNM itself is ETS 157 (February 1995). 
performance vis à vis those obligations. ${ }^{189}$ That a UN body should file a report to a UN treaty body indicates how rule of law might be expected to work; that UNMIK filed a series of reports under a treaty promulgated by the Council of Europe has gone largely unnoticed in discussions on monitoring rule of law and speaks of how accountability can be achieved. ${ }^{190}$ That said, UNMIK along with the UN Transitional Administration in East Timor were peculiarly able to accept such responsibilities, while other UN operations are not so formalized, although that does not mean special arrangements could not be established, especially in relation to Universal Periodic Review and UN Special Procedures. ${ }^{191}$ Internal oversight mechanisms, such as those within UNMIK, first the Ombudsperson Institution and, after 2006, the Human Rights Advisory Panel, ${ }^{192}$ are a further example of a flexible means for establishing ad hoc oversight over UN operations. In international law generally, non-judicial remedies 'are the norm, not the exception', ${ }^{193}$ so accountability for the UN can

${ }^{189}$ As regards the report to the Human Rights Committee by UNMIK, see 'Concluding Observations of the Human Rights Committee' (27 July 2006), Serbia, UN doc $\mathrm{CCPR} / \mathrm{C} / \mathrm{UNK} / \mathrm{CO} / 1$ (2006): with respect to the FCNM, UNMIK filed reports in 2005, 2008 and $2012<$ http://www.coe.int/en/web/minorities/country-specificmonitoring\#UNMIK_Kosovo>.

${ }^{190}$ See also, Kadi (n 65, but while the ECJ reviewed the Security Council decision, it did not hold the Security Council to account. In relation to the Security Council's 1267 sanctions regime, UNSC res 1267 (1999) (but see now $<$ https://www.un.org/sc/suborg/en/sanctions/1267>), the Security Council has created the 1267 Ombudsperson $<$ https://www.un.org/sc/suborg/en/ombudsperson> under UNSC res 1904 (2009), see generally Hovell (n 17) 24ff; and Bank Mellat v HM Treasury [2013] UKSC 38, [2015] EWCA Civ 105, [2016] EWCA Civ 452.

${ }^{191}$ See Marshall (n 50 115-18. See also Bianchi (n 61.

192 UNMIK/REG/2000/38 (30 June 2000); and UNMIK/REG/2006/12 (23 March 2006). Also see Verdirame (n 159 260ff; Gemma Woods and Sarah Mace, 'Connecting humanitarian actors and displaced communities: the IDP call centre in Iraq' (The Humanitarian Practice Network, October 2015) <http://odihpn.org/magazine/connectinghumanitarian-actors-and-displaced-communities-the-idp-call-centre-in-iraq/>; and Florian Hoffmann and Frédéric Mégret, 'Fostering Human Rights Accountability: An Ombudsperson for the United Nations?' (2005) 11 Global Governance 43.

193 See Alvarez (n 12) 39-40. 
be through a range of mechanisms and procedures, of the type set out in article 33 of the Charter. Nevertheless, a shadow still hanging over the internal operationalization of rule of law in the UN is the example of the cholera outbreak in Haiti: after many years, the UN acknowledged its responsibility in 2016 but still asserted its immunity, without establishing an internal mechanism to provide a remedy to victims. ${ }^{194}$ Thus, the obligation set out in the 2012 General Assembly Resolution for the UN to observe the rule of law and for that to be monitored to ensure compliance could, with the necessary political will, be effected.

Moreover, monitoring emphasizes the need for UN organs to co-operate in order to fulfil all the rights and meet all the needs of individuals of concern, as discussed above. ${ }^{195}$

\section{CONCLUSION}

This article has shown how rule of law is understood in the UN. Previous work has focused on assessing past operations or on content alone: here, the focus has been on operationalization and, also, the interoperability of the different parts of the UN, which have all adopted their own stance in terms of the Secretary-General's 2004 report. Having set out the scope of rule of law that the UN embraces, the article then discussed the different elements in some detail, as they have been applied and might be applied to populations affected by displacement because of the complexity of that particular crucible. Finally, and significantly, it showed how the UN has to adopt rule of law standards in its dealings with individuals within the scope of its actions, and how that might also facilitate interoperability within the UN.

In sum, rule of law, as has been demonstrated, has many meanings and more than one interpretation: constitutionalized, post-1945 Rechtsstaat in many ways better encapsulates

\footnotetext{
${ }^{194}$ See Statement attributable to the Spokesman for the Secretary-General on Haiti, 19 August $2016<\mathrm{https} / /$ www.un.org/sg/en/content/sg/statement/2016-08-19/statementattributable-spokesman-secretary-general-haiti>. Also see Hovell (n 17) 43. See also Delama Georges $v$ United Nations 84 F.Supp 3d 246, 162 ILR 775 (9 January 2015) para 16, asserting the absolute immunity of the UN, MINUSTAH, and the Secretary-General; Jam v International Finance Corporation (No 15-612, DDC, 2016); and José Alvarez, 'The UN in the Time of Cholera' (American Journal of International Law Unbound, 4 April 2014) $<$ https://www.asil.org/blogs/united-nations-time-cholera $>$.

${ }^{195}$ See part 3.3.2(c), Protection, solutions, and rule of law.
} 
the idea of rule of law within the UN system. ${ }^{196}$ The UN was not founded on a full application of rule of law as it is understood at the domestic level, but there are signs of greater application. Its theoretical underpinnings are equally multifarious. Within the UN, the importance of rule of law is that it provides a helpful and flexible framework for building the capacity of States and for protecting all individuals so that they might enjoy the full panoply of their rights and their needs might be met, including all those found within the State after displacement. It renders any distinction between humanitarian and development activities otiose, as the focus is on promoting justice solutions over time for individuals. As such, rule of law provides a framework for interoperability within the UN that is essential if all those rights and needs are to be fulfilled and satisfied by the State and by the UN. ${ }^{197}$ However, with that usefulness of the approach must come the obligation for the UN to accept accountability to individuals of concern.

\footnotetext{
${ }^{196}$ Indeed, there are times when the UN approach reminds one of Humpty Dumpty's views on the meaning of words, Lewis Carroll, Through The Looking Glass, and What Alice Found There (1871, rep 1998) 190: 'When I use a word [or phrase], ..., it means just what I choose it to mean - neither more nor less'. Also see Loughlin's critique of rule of law (n 3). ${ }^{197}$ See Harlow (n 14) 210-11.
} 